\title{
Immune-Regulatory and Molecular Effects of Antidepressants on the Inflamed Human Keratinocyte HaCaT Cell Line
}

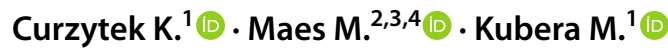

Received: 2 November 2020 / Revised: 18 April 2021 / Accepted: 19 April 2021 / Published online: 4 May 2021

(c) The Author(s) 2021

\begin{abstract}
Allergic contact dermatitis (ACD) is a T cell-mediated type of skin inflammation resulting from contact hypersensitivity (CHS) to antigens. There is strong comorbidity between ACD and major depression. Keratinocytes release immunomodulatory mediators including pro-inflammatory cytokines and chemokines, which modulate skin inflammation and are crucial cell type for the development of CHS. Our previous studies showed that fluoxetine and desipramine were effective in suppressing CHS in different mouse strains. However, the immune and molecular mechanisms underlying this effect remain to be explored. The aim of the current study was to determine the immune and molecular mechanisms of action of antidepressant drugs engaged in the inhibition of CHS response in the stimulated keratinocyte HaCaT cell line. The results show that LPS, TNF- $\alpha /$ IFN- $\gamma$, and DNFB stimulate HaCaT cells to produce large amounts of pro-inflammatory factors including IL-1 $\beta$, IL-6, CCL2, and CXCL8. HaCaT stimulation was associated with increased expression of ICAM-1, a cell adhesion molecule, and decreased expression of E-cadherin. Imipramine, desipramine, and fluoxetine suppress the production of IL-1 $\beta$, CCL2, as well as the expression of ICAM-1. LPS and TNF- $\alpha$ /IFN- $\gamma$ activate p-38 kinase, but antidepressants do not regulate this pathway. LPS decreases E-cadherin protein expression and fluoxetine normalizes these effects. In summary, the antidepressant drugs examined in this study attenuate the stimulated secretion of pro-inflammatory cytokines, chemokines, and modulate adhesion molecule expression by the $\mathrm{HaCaT}$ cell line. Therefore, antidepressants may have some clinical efficacy in patients with ACD and patients with comorbid depression and contact allergy.
\end{abstract}

Keywords Antidepressant drugs $\cdot$ Contact hypersensitivity $\cdot$ Depression $\cdot$ Cytokines $\cdot$ Adhesion molecules

\section{Introduction}

In humans, the progressive industrialization and the associated development of the chemical industry have increased the exposure to a large variety of chemicals. Some of these may function as haptens of low molecular weight that are capable of inducing delayed-type hypersensitivity (DTH),

Kubera M.

kubera@if-pan.krakow.pl

1 Department of Experimental Neuroendocrinology, Maj Institute of Pharmacology Polish Academy of Sciences, Kraków, Poland

2 Department of Psychiatry, Faculty of Medicine, King Chulalongkorn Memorial Hospital, Bangkok, Thailand

3 Department of Psychiatry, Medical University of Plovdiv, Plovdiv, Bulgaria

4 IMPACT Strategic Research Centre, Deakin University, PO Box 281, Geelong, VIC 3220, Australia which is an immune response that develops at the site of hapten exposure and is a classical form of $\mathrm{T}$ cell-mediated immunity (Blauvelt et al. 2003). Allergic contact dermatitis (ACD) is the most common type of DTH in humans. Contact dermatitis (CD) affects approximately $20 \%$ of the general population, whereas occupational CD constitutes up to $30 \%$ of all occupational diseases (Thyssen et al. 2007; Diepgen and Weisshaar 2007). The number of etiologic CD factors is very high and is still growing with over 3700 haptens being identified (Martin et al. 2004). The ever-growing number of patients suffering from this disease adversely affects patients' productivity and health-related quality of life. In contact hypersensitivity responses, there are two phases: an induction phase after the priming contact with a hapten and an elicitation phase that develops after re-exposure to the hapten (Kimber and Dearman 2002). A wide variety of cells (dendritic cells, endothelial cells, mastocytes, keratinocytes, melanocytes, monocytes, neutrophils, and antigen-specific 
T lymphocytes) and pro-inflammatory factors are involved in both stages (Majewska and Szczepanik 2009).

The skin is the largest organ of the body with an area of approx. $2 \mathrm{~m}^{2}$ representing $15 \%$ of total body weight (Dąbrowska et al. 2018). The skin barrier comprises local skin cells, including keratinocytes, mast cells, and immune cells, and is, in fact, a component of the immune system (Blauvelt et al. 2003). There is a tight association between the skin and the nervous system which is formed as early as in utero since both organs develop from the ectodermal leaf. Furthermore, there are multiple feedback signals between the skin and the brain, which are mediated by inflammatory cytokines and neuro-immune pathways (Chen and Lyga 2014; Farzanfar et al. 2018).

There is a strong comorbidity between skin diseases and major depression (Dalgard et al. 2015; Marron et al. 2018) with exposure to stress affecting both the exacerbation of allergic reactions and depressive episodes (Niemeier et al. 2002). There is now evidence that depression is accompanied by activation of the immune-inflammatory response system (IRS) marked by increased levels of pro-inflammatory cytokines, such as interleukin (IL)-1, IL-6, tumor necrosis factor (TNF)- $\alpha$, and interferon (IFN)- $\gamma$ in the blood (Maes et al. 1991, 2009; Kubera et al. 2001, 2011b; Faugere et al. 2018; Dubois et al. 2018). Pro-inflammatory cytokines released in the periphery may cross the blood-brain barrier and affect microglia, which are probably involved in the pathophysiology of major depressive disorders (Troubat et al. 2020; Qin et al. 2007).

Antidepressants are used to treat major depression and these effects are in part explained by their immune-regulatory properties. In vitro studies revealed the dose-dependent ability of antidepressants to reduce the production of pro-inflammatory cytokines including TNF- $\alpha$, IFN- $\gamma$, IL- 6 , and IL- $1 \beta$ by human lymphocytes and monocytes (Kubera et al. 2009; Xia et al. 1996). In animal models of depression, antidepressants reduce the production of IFN- $\gamma$ and enhance the synthesis of IL-10 (Maes et al. 1999; Kubera et al. 2001).

Based on these findings, we have hypothesized that antidepressant drugs may have some efficacy in the treatment of contact hypersensitivity (CHS).

Our previous studies revealed that repeated administration of antidepressant drugs was effective in inhibiting CHS reactions to picryl chloride (PCL) in CBA/J mice and 2,4-dinitrofluorobenzene (DNFB) in Balb/c mice (Kubera et al. 2012; Curzytek et al. 2013). Fourteen-day treatment with antidepressants (10 days before immunization with a hapten and 4 days during this process) with both fluoxetine (a selective serotonin reuptake inhibitor, SSRI) and desipramine (a tricyclic antidepressant, TCA) used in two strains of mice inhibited CHS reactions by approximately $50 \%$. Antidepressant treatment additionally reduced the production of the pro-inflammatory cytokines IL- 6 and IFN- $\gamma$ by concanavalin A (Con A)-stimulated splenocytes (Curzytek et al. 2013). Furthermore, the administration of both fluoxetine and desipramine during sensitization increased IL-10 production by Con A-stimulated splenocytes in a PCL model of CHS (Kubera et al. 2012) and by Con A-stimulated lymph node cells in a DNFB model of sensitization (Curzytek et al. 2013). Nazimek et al. (2016) showed that 6-day administration of imipramine, fluoxetine, and venlafaxine, before and during immunization with a hapten (PCL), attenuated CHS reactions in CBA/J mice by about $20 \%$. These experimental investigations showed the effectiveness of antidepressants in inhibiting CHS responses. Nevertheless, the immune and molecular mechanisms underlying these anti-allergic effects remain unknown.

The present study aimed to investigate the mechanism of action of antidepressants in a cellular model of CHS using the activated human keratinocyte cell line HaCaT. Keratinocytes are the first cells involved in the response to chemicals contacting the skin and are, therefore, important in both the induction and elicitation phases of CHS responses. Due to the anatomical location of keratinocytes and their important role in inflammatory skin diseases, the use of keratinocytes in studies on the mechanisms underlying contact allergy is fully justified and commonly applied (Aye et al. 2020; Galbiati et al. 2011; Choi et al. 2013).

The aim of our study was to determine whether antidepressants have an anti-inflammatory effect on stimulated $\mathrm{HaCaT}$ cells. Toward this end, we investigated how antidepressants affect the secretion of cytokines, chemokines, cell adhesion molecule expression, and protein kinases by the stimulated keratinocytes $\mathrm{HaCaT}$ cell line.

\section{Materials and Methods}

\section{Chemicals and Drugs}

The following drugs were used: fluoxetine hydrochloride (Flu), desipramine hydrochloride (Des), and imipramine hydrochloride (Imi), all of which were obtained from Sigma-Aldrich, Germany. The following stimulants were used: lipopolysaccharide (LPS; 026:B6, Sigma-Aldrich, Germany), recombinant human TNF- $\alpha$ (Gibco, UK), recombinant human IFN- $\gamma$ (Gibco, UK), and 1-fluoro2,4-dinitrobenzene (DNFB; Sigma-Aldrich, Germany). The stock solutions of fluoxetine and DNFB were prepared in DMSO. A final concentration of the tested chemicals was prepared in distilled water, and the solvent was present in the cell culture at a final concentration of $0.01 \%$. Desipramine and imipramine were dissolved in distilled water. LPS and TNF- $\alpha / \mathrm{IFN}-\gamma$ were dissolved in the culture medium. Each experimental set of the control cultures was supplemented with the appropriate vehicle. 


\section{Cell Culture}

The human immortalized keratinocyte cell line (HaCaT) was purchased from CLS (Germany). The HaCaT cells were cultured in DMEM medium, supplemented with $10 \%$ FBS and $1 \%$ antibiotics (100 units/ml penicillin and $100 \mathrm{mg} / \mathrm{ml}$ streptomycin), and all reagents were obtained from Gibco, UK. The cells were cultured at $37^{\circ} \mathrm{C}$ in a humidified atmosphere with $5 \% \mathrm{CO}_{2}$. Cell cultures were carried out in 75 $\mathrm{cm}^{2}$ culture bottles. The cells were passaged once a week, in a volume ratio of 1:10. The cells were trypsinized with $0.05 \%$ Trypsin and $1 \mathrm{mM}$ EDTA for $5 \mathrm{~min}$ at $37^{\circ} \mathrm{C}$ from the bottom of the culture bottle. Cultures with a different number of cells were used for the tests, depending on the type of plates used and tests performed: 96-well plate $5 \times 10^{4}$ cells/well (for LDH release, MTT assay), 24-well plate $-5 \times 10^{5}$ cells/well (enzyme-linked immunosorbent assay (ELISA) assay), and 6-well plate $-1 \times 10^{6}$ cells/well (Western blot, quantitative real-time polymerase chain reaction (qRT-PCR)). On the day preceding the experiment, the culture medium was changed to DMEM with $1 \%$ FBS as well as penicillin/streptomycin antibiotics. The time of cell exposure to stimulants and antidepressants varied depending on the type of experiment. Drugs were added to cell cultures always $30 \mathrm{~min}$ before adding the appropriate stimulants. The control group was treated with a vehicle.

\section{Cell Viability Assay}

The HaCaT cells were treated with various concentrations of antidepressants (Flu: 0.1-50 $\mu \mathrm{M}$; Des: 0.1-10 $\mu \mathrm{M}$, Imi: $0.1-10 \mu \mathrm{M}$ ) and stimulants (LPS: $0.5-10 \mu \mathrm{g} / \mathrm{ml}$; TNF- $\alpha /$ IFN- $\gamma$ : 1-50 ng/ml; DNFB: 0.01-50 $\mu \mathrm{M}$ ) for $24 \mathrm{~h}$. Subsequently, the MTT solution was added to each well (at a final concentration of $0.15 \mathrm{mg} / \mathrm{ml}$ ) and incubated over $30 \mathrm{~min}$ at a temperature of $37{ }^{\circ} \mathrm{C}$. The incubation was halted by the addition of $100 \%$ DMSO into each well, solubilizing the formazan. The absorbance at $\lambda=570 \mathrm{~nm}$ was measured using a microplate reader (Tecan, Infinite M200PRO). The data were normalized to vehicle-treated cells $(100 \%)$ and expressed as a percent of control \pm SEM established from at least 3 independent experiments with 5 replicates.

\section{LDH Release Assay}

The amount of lactate dehydrogenase (LDH) released into culture media from $\mathrm{HaCaT}$ cells after $24 \mathrm{~h}$ of treatment with antidepressants and stimulants was measured with the Cytotoxicity Detection Kit (Roche). Briefly, part of the cell-free medium was removed, then the mixture of reagents supplied by the kit manufacturer was added and after 15 min of incubation at room temperature, absorbance at $\lambda=490 \mathrm{~nm}$ was measured using a microplate reader (Tecan, Infinite
M200PRO). The data were normalized to vehicle-treated cells (100\%) and expressed as a percent of control \pm SEM established from at least 3 independent experiments with 5 replicates.

\section{Enzyme-Linked Immunosorbent Assay}

The production of pro-inflammatory factors: IL-1 $\beta$, IL-6, CXCL8 (IL-8), and CCL2 (MCP-1) was measured with the eBioscience ELISA Ready-SET-Go kit (USA) according to the manufacturer's instructions. The level of each interleukin was measured in cell supernatants or cell lysates (IL$1 \beta$ ) from cell cultures, after $24 \mathrm{~h}$ of incubation with antidepressants and stimulants. The absorbance at $\lambda=450 \mathrm{~nm}$ was measured using a microplate reader (Tecan, Infinite M200PRO). The level of ICAM-1 was measured using the ELISA kit Peprotech (UK) and the level of E-cadherin was measured in cell lysates using the ELISA kit Life Technologies (USA), following the supplier's recommendations.

\section{Western Blot}

Western blot analysis was conducted to determine the level of kinase activation. Cell lysates were collected. One hour after the treatment of $\mathrm{HaCaT}$ cells with antidepressants (Flu 0.1 and $0.5 \mu \mathrm{M}$; Des 1 and $5 \mu \mathrm{M}$; Imi $1 \mu \mathrm{M}$ ) and stimulants (LPS: $3 \mu \mathrm{g} / \mathrm{ml}$; TNF- $\alpha / \mathrm{IFN}-\gamma$ : $10 \mathrm{ng} / \mathrm{ml}$; DNFB: $1 \mu \mathrm{M}$ ), samples containing an equal amount of protein were separated by SDS-PAGE (4-20\% gel; Bio-Rad, Hercules, CA, USA) and transferred to PVDF membranes (Trans-Blot Turbo; Bio-Rad, Hercules, CA, USA). After the transfer, the membranes were cut to allow simultaneous (overnight at $4{ }^{\circ} \mathrm{C}$ ) incubation with different primary antibodies (anti-NFkB p65 (sc-372), anti-phospho-NFкB p65 (sc-33020), anti-IкB- $\alpha$ (sc-1643), anti-phospho-IкB- $\alpha$ (sc-8404), anti-NIK (sc7211), anti-phospho-NIK (sc-12957), anti-p38 (sc-7972), and anti-phospho-p38 (sc-101759)) obtained from Santa Cruz Biotechnology (USA) and anti-GAPDH (MAB374, Millipore, USA). The next day, the membranes were washed four times with TBS containing $0.1 \%$ Tween-20 (TBST) and then incubated with appropriate secondary antibodies (Vector Laboratories, UK) for $1 \mathrm{~h}$ at room temperature. The immunoblots were visualized with a chemiluminescence detection kit (Roche, Germany). The data obtained were normalized to the level of reference proteins and then averaged and presented as a percentage of control \pm SEM, from at least three independent experiments.

\section{Quantitative Real-Time Polymerase Chain Reaction}

Total RNA was extracted from $\mathrm{HaCaT}$ cells using the Universal RNA Purification Kit (Eurx, Poland), according to the instructions provided by the manufacturer. Identical amounts 
of RNA $(1 \mu \mathrm{g})$ were reverse transcribed into complementary DNA (cDNA) using a commercial RT-PCR kit (HighCapacity cDNA Reverse Transcription Kit, Applied Biosystems, USA). The cDNA was subsequently amplified using TaqMan probes and primers for the following genes: ICAM-1 (Hs00164932_m1) and E-cadherin (Hs01023894_m1) were obtained from the Life Technologies (USA), with the FastStart Universal Probe Master (Rox) kit (Roche, Basel, Switzerland). The threshold value $\left(C_{t}\right)$ for each sample was set in the exponential phase of PCR, and the $\Delta \Delta C_{\mathrm{t}}$ method was used for data analysis. Glyceraldehyde 3-phosphate dehydrogenase (GAPDH (Hs02758991_g1)) was used as the reference gene.

\section{Immunocytochemistry}

HaCaT cells were seeded into LabTek II CC2 (Nunc, Thermo Fisher Scientific, USA) chambers coated with poly-o-lysine $(0.01 \mathrm{mg} / \mathrm{ml})$ at a density of $5 \times 10^{4}$ per well. The cultures were grown for $48 \mathrm{~h}$, then the culture medium was changed to $1 \%$ FBS serum content and then incubated with antidepressants (all drugs were used at the maximum concentrations) and stimulants (LPS and TNF- $\alpha / \mathrm{IFN}-\gamma$ ) for $1 \mathrm{~h}$ (anti-ICAM-1 conjugated to PE; orb124670, Biorbyt, UK) and for $24 \mathrm{~h}$ (anti-E-cadherin, conjugated to FITC; orb15536, Biorbyt, UK). Then, the cells were washed with PBS buffer and fixed with 4\% paraformaldehyde in PBS for $10 \mathrm{~min}$ at room temperature. After three more washes with PBS buffer, the chambers were incubated for $10 \mathrm{~min}$ in an incubator at $95{ }^{\circ} \mathrm{C}$, in the buffer revealing antigenic determinants (antigen retrieval buffer; $100 \mathrm{mM}$ Tris, $5 \%$ urea, $\mathrm{pH}$ 9.5). Next, the chambers were again washed three times with PBS, and then the cells were blocked for $30 \mathrm{~min}$ in $1 \% \mathrm{BSA}$ in PBST buffer (PBS $+0.1 \%$ Tween 20). The next step was a 1-h incubation with fluorochrome-labeled antibodies at room temperature in the dark. After the incubation, the chambers were again washed 3 times with PBS buffer. The plastic chambers were then removed from the slides and the stained slides were embedded in the VECTASHIELD ${ }^{\circledR}$ Antifade Mounting Medium with DAPI (Vector Laboratories, USA) and protected with a coverslip. Cells were visualized using a Leica TCS SP8 WLL confocal microscope, and image processing was performed using the Leica Application Suite X software (Leica, Germany).

\section{Statistical Analysis}

The data were normalized and analyzed using the Statistica software, version 13 (StatSoft Inc., USA). Differences between group means were analyzed using a two-factor analysis of variance (factorial ANOVA) followed by Tukey's post hoc analysis. The differences were considered significant at $p<0.05$.

\section{Results}

\section{The Cytotoxicity Assessment of Tested Drugs and Stimulants}

The cytotoxicity of both antidepressant drugs and stimulants in $\mathrm{HaCaT}$ keratinocytes was determined using the MTT reduction test and the lactate dehydrogenase (LDH) release test (Table 1). After $24 \mathrm{~h}$ of incubation, fluoxetine (Flu) in the concentration range of 0.1 to $5 \mu \mathrm{M}$ was not toxic to the cells. A decrease in viability of $\mathrm{HaCaT}$ cells in the MTT test was only observed when using $50 \mu \mathrm{M}$ fluoxetine $(p<0.05)$, while a fivefold increase in the level of LDH released into the culture medium had already been observed at the concentration of $10 \mu \mathrm{M}(p<0.05)$ (Table 1). However, the lowest tested drug concentrations were selected for a further study due to the slightly elevated (but statistically insignificant) levels of LDH released into the medium at $1 \mu \mathrm{M}$ fluoxetine and the results of pilot experiments that indicated its cytotoxic activity at $1 \mu \mathrm{M}$.

Desipramine (Des) was not toxic to cells over the concentration range of $0.1-5 \mu \mathrm{M}$. In contrast, at the concentration of $10 \mu \mathrm{M}$, it showed a toxic effect on the cells, observed as a significant decrease in viability in the MTT test, and a simultaneous increase in the level of released LDH $(p<0.05)$ (Table 1).

The incubation of cells with imipramine (Imi) did not affect cell viability in the $0.1-1 \mu \mathrm{M}$ concentration range. A decrease in viability was observed in the range of 5-10 $\mu \mathrm{M}(p<0.05)$, while neither concentration of imipramine resulted in an increase in LDH secretion into the medium (Table 1).

Based on these results, we selected two concentrations of fluoxetine $(0.1$ and $0.5 \mu \mathrm{M})$ and desipramine $(1$ and $5 \mu \mathrm{M})$, and $1 \mu \mathrm{M}$ imipramine (Table 1 ) to examine the effects of antidepressants on the stimulated production of the biomarkers.

Using the above-mentioned tests, LPS was non-toxic to cells in the concentration range of $0.5-3 \mu \mathrm{g} / \mathrm{ml}$ (Table 1), TNF- $\alpha / \mathrm{IFN}-\gamma$ in the range of $0.5-10 \mu \mathrm{g} / \mathrm{ml}$ (Table 1), and DNFB from $10 \mathrm{nM}$ to $1 \mu \mathrm{M}$ (Table 1 ). The maximum nontoxic stimulant concentrations for the cultures were selected for further experiments, namely LPS at $3 \mu \mathrm{g} / \mathrm{ml}$, TNF- $\alpha / \mathrm{IFN}-\gamma$ at $10 \mathrm{ng} / \mathrm{ml}$, and DNFB at $1 \mu \mathrm{M}$ (Table 1). Finally, the combination of stimulants and antidepressants did not significantly affect the MTT test or the LDH release (Table 1).

\section{Effects of Antidepressant Drugs on the Production of Cytokines and Chemokines in LPS-, TNF-a/IFN- - -, or DNFB-stimulated HaCaT cells}

LPS-treated HaCaT keratinocytes showed a threefold increase $(p<0.05)$ in IL-1 $\beta$ production. Pretreatment of $\mathrm{HaCaT}$ cells with antidepressants tended to reduce IL-1 $\beta$ 
Table 1 The effect of the antidepressant drugs and stimulants on the viability of $\mathrm{HaCaT}$ cells

\begin{tabular}{|c|c|c|}
\hline & $\%$ of cell viability & $\%$ of $\mathrm{LDH}$ release \\
\hline \multicolumn{3}{|l|}{ Drugs } \\
\hline Control & $100.00 \pm 2.09$ & $100.00 \pm 1.74$ \\
\hline Fluoxetine $($ Flu) $[\mu \mathrm{M}] \mathbf{0 . 1}$ & $97.61 \pm 3.29$ & $98.78 \pm 1.32$ \\
\hline 0.5 & $96.87 \pm 1.32$ & $87.35 \pm 1.53$ \\
\hline 1 & $95.60 \pm 1.81$ & $108.69 \pm 1.19$ \\
\hline 5 & $93.27 \pm 2.30$ & $91.46 \pm 1.01$ \\
\hline 10 & $102.91 \pm 3.06$ & $523.55 \pm 50.56^{*}$ \\
\hline 50 & $5.00 \pm 0.52 *$ & $557.80 \pm 8.15^{*}$ \\
\hline Control & $100.00 \pm 1.23$ & $100.00 \pm 3.01$ \\
\hline Desipramine (Des) $[\mu \mathrm{M}] 0.1$ & $97.05 \pm 1.40$ & $87.34 \pm 1.29$ \\
\hline 1 & $99.95 \pm 1.28$ & $93.92 \pm 3.21$ \\
\hline 5 & $93.91 \pm 1.82$ & $92.73 \pm 2.28$ \\
\hline 10 & $91.79 \pm 1.24^{*}$ & $113.83 \pm 3.76^{*}$ \\
\hline Control & $100.00 \pm 1.94$ & $100.00 \pm 1.86$ \\
\hline Imipramine (Imi) $[\mu \mathrm{M}] 0.1$ & $99.40 \pm 1.91$ & $88.02 \pm 2.70$ \\
\hline 1 & $94.70 \pm 1.65$ & $87.23 \pm 2.80$ \\
\hline 5 & $85.50 \pm 2.35^{*}$ & $84.94 \pm 3.85^{*}$ \\
\hline 10 & $78.10 \pm 2.70^{*}$ & $70.82 \pm 3.17 *$ \\
\hline \multicolumn{3}{|l|}{ Stimulants } \\
\hline Control & $100.00 \pm 2.00$ & $100.06 \pm 1.62$ \\
\hline LPS $[\mu \mathrm{g} / \mathrm{ml}] 0.5$ & $97.50 \pm 2.82$ & $96.28 \pm 2.18$ \\
\hline 1 & $96.17 \pm 2.54$ & $92.11 \pm 1.65^{*}$ \\
\hline 3 & $96.60 \pm 1.86$ & $93.79 \pm 1.47$ \\
\hline 5 & $81.19 \pm 2.51^{*}$ & $99.39 \pm 3.08$ \\
\hline 10 & $80.32 \pm 2.34^{*}$ & $111.69 \pm 1.67 *$ \\
\hline Control & $100.00 \pm 1.10$ & $100.00 \pm 1.64$ \\
\hline TNF- $\alpha / \mathrm{IFN}-\gamma[\mathrm{ng} / \mathrm{ml}] 1$ & $98.62 \pm 1.20$ & $102.16 \pm 1.49$ \\
\hline 5 & $96.07 \pm 1.46$ & $96.55 \pm 1.75$ \\
\hline 10 & $95.36 \pm 0.87$ & $98.54 \pm 1.55$ \\
\hline 20 & $93.47 \pm 2.24^{*}$ & $91.89 \pm 2.18^{*}$ \\
\hline 50 & $91.91 \pm 2.19^{*}$ & $112.69 \pm 1.81^{*}$ \\
\hline Control & $100.00 \pm 3.05$ & $100.00 \pm 7.84$ \\
\hline DNFB $[\mu \mathrm{M}] 0.01$ & $93.63 \pm 5.17$ & $80.40 \pm 3.01$ \\
\hline 0.1 & $86.70 \pm 2.61$ & $62.01 \pm 3.34$ \\
\hline 1 & $88.89 \pm 3.42$ & $88.34 \pm 7.38$ \\
\hline 10 & $8.46 \pm 1.96^{*}$ & $518.97 \pm 45.58^{*}$ \\
\hline 50 & $2.44 \pm 0.20 *$ & $774.23 \pm 14.32 *$ \\
\hline \multicolumn{3}{|l|}{ Drugs + Stimulants } \\
\hline LPS 3 + Flu 0.1 & $102.77 \pm 2.38$ & $86.98 \pm 2.99$ \\
\hline LPS $3+$ Flu 0.5 & $100.78 \pm 3.06$ & $91.46 \pm 3.10$ \\
\hline LPS $3+$ Des 1 & $89.81 \pm 7.13$ & $97.65 \pm 1.79$ \\
\hline LPS $3+$ Des 5 & $88.97 \pm 2.36$ & $106.09 \pm 5.28$ \\
\hline LPS $3+\operatorname{Imi} 1$ & $99.50 \pm 2.19$ & $101.07 \pm 2.71$ \\
\hline TNF- $\alpha /$ IFN- $\gamma 10+$ Flu 0.1 & $96.56 \pm 2.58$ & $112.45 \pm 3.44$ \\
\hline TNF- $\alpha /$ IFN- $\gamma 10+$ Flu 0.5 & $91.43 \pm 4.34$ & $106.63 \pm 5.12$ \\
\hline TNF- $\alpha / \mathrm{IFN}-\gamma 10+$ Des 1 & $95.14 \pm 2.87$ & $112.86 \pm 6.04$ \\
\hline TNF- $\alpha / \mathrm{IFN}-\gamma 10+$ Des 5 & $87.96 \pm 2.53$ & $117.80 \pm 7.66$ \\
\hline TNF- $\alpha /$ IFN- $\gamma 10+\operatorname{Imi~} 1$ & $91.35 \pm 2.98$ & $110.79 \pm 7.83$ \\
\hline DNFB $1+$ Flu 0.1 & $95.83 \pm 1.68$ & $93.94 \pm 6.52$ \\
\hline
\end{tabular}

Table 1 (continued)

\begin{tabular}{lll}
\hline & \% of cell viability & \% of LDH release \\
\hline DNFB 1 + Flu 0.5 & $92.98 \pm 1.88$ & $94.03+6.76$ \\
DNFB 1 + Des 1 & $93.84 \pm 3.37$ & $93.19 \pm 5.31$ \\
DNFB 1 + Des 5 & $86.19 \pm 2.51$ & $106.65 \pm 7.13$ \\
DNFB 1 + Imi 1 & $96.77 . \pm 2.67$ & $94.87 \pm 3.31$ \\
\hline
\end{tabular}

Cells were treated with the fluoxetine $(0.1-50 \mu \mathrm{M})$, desipramine $(0.1-$ $10 \mu \mathrm{M})$, imipramine $(0.1-10 \mu \mathrm{M})$, and LPS $(0.5-10 \mu \mathrm{g} / \mathrm{ml})$, TNF- $\alpha /$ IFN- $\gamma(1-50 \mathrm{ng} / \mathrm{ml})$, or DNFB $(0.01-50 \mu \mathrm{M})$ for $24 \mathrm{~h}$, after which cell viability (MTT assay) and the level of released LDH were measured. The bold concentration values of individual substances were selected for further experiments. The results in the groups with combined stimulation of the cells by drugs and stimulants were compared with the appropriate control group (vehicle-treated cells) as well as the corresponding groups treated by drugs or stimulants alone. Data are shown as the mean of $\%$ of control \pm SEM from at least 3 separate experiments with 5 replicates each. $* p<0.05$ vs. control cells

secretion and only desipramine $(1 \mu \mathrm{M}, p<0.05)$ significantly inhibited the production of IL- $1 \beta$ in LPS-stimulated cells (Fig. 1a).

When stimulating HaCaT cells with a TNF- $\alpha /$ IFN- $\gamma$, a tenfold increase in IL-1 $\beta$ secretion was observed $(p<0.05)$ and fluoxetine at $0.1 \mu \mathrm{M}(p<0.05)$ and desipramine at both concentrations $(p<0.05)$ reduced the level of secreted IL-1 $\beta$ (Fig. 1a).

Although we observed a tendency toward increased production of IL-6 in LPS-treated HaCaT cells, this change did not reach statistical significance. Furthermore, the antidepressants examined here did not affect this parameter (Fig. 1b).

Upon the TNF- $\alpha / \mathrm{IFN}-\gamma$ stimulation of HaCaT, the cells produced three times more IL-6 $(p<0.05)$. Desipramine pretreatment for $30 \mathrm{~min}$, at both 1 and $5 \mu \mathrm{M}(p<0.05)$, reduced the TNF- $\alpha / \mathrm{IFN}-\gamma$-evoked increase in the IL- 6 production (Fig. 1b).

The stimulation of HaCaT cells using DNFB or antidepressants, as well as both factors simultaneously, did not lead to changes in the secretion of IL-6 into the medium (Fig. 1b).

LPS significantly upregulated CCL2 (MCP-1) in the HaCaT culture medium $(p<0.05)$ in comparison to vehicletreated cells. Moreover, desipramine at both concentrations ( 1 and $5 \mu \mathrm{M}, p<0.05)$ and imipramine $(p<0.05)$ significantly weakened the effect of LPS (Fig. 1c).

We observed that $24 \mathrm{~h}$ of TNF- $\alpha / \mathrm{IFN}-\gamma$ stimulation upregulated the release of CCL2 up to 35 -fold $(p<0.05)$ when compared to vehicle-treated cells. Furthermore, we observed that desipramine at concentrations 1 and $5 \mu \mathrm{M}$ $(p<0.05)$ and fluoxetine at a lower dose $(p<0.05)$ effectively decreased the TNF- $\alpha / \mathrm{IFN}-\gamma$-evoked upregulation in the chemokine secretion (Fig. 1c). 
a

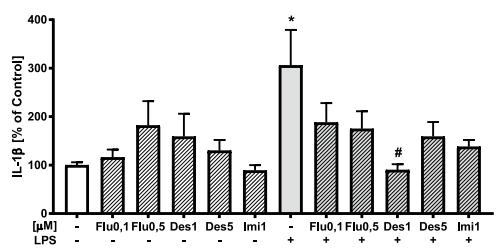

b

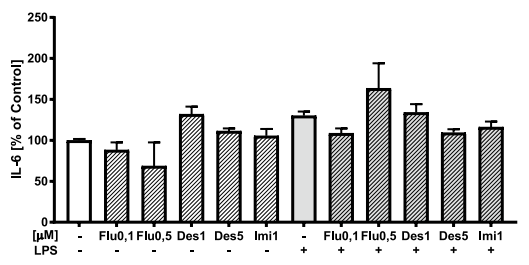

C

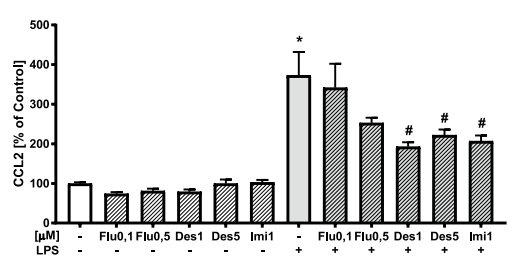

d

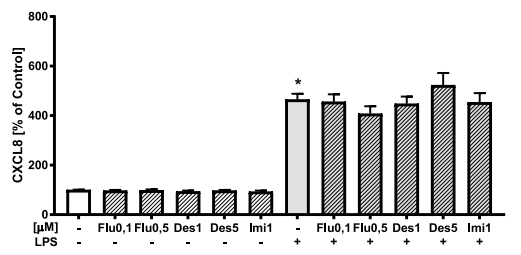

IL-1 $\beta$

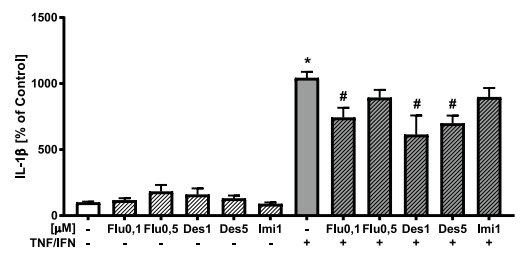

IL-6
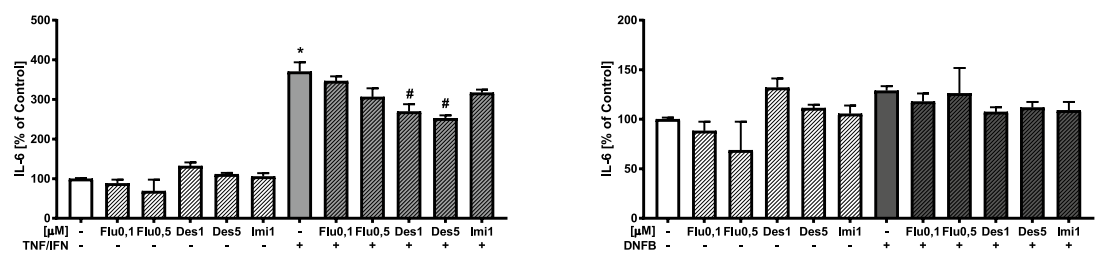

CCL2
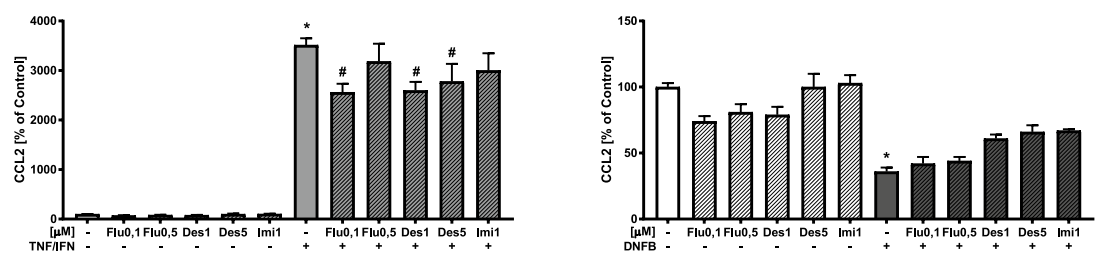

CXCL8

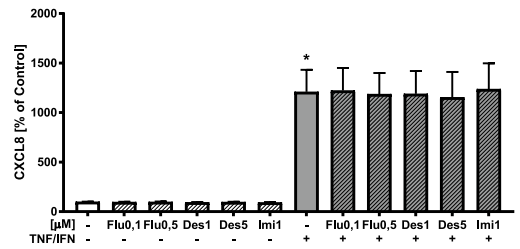

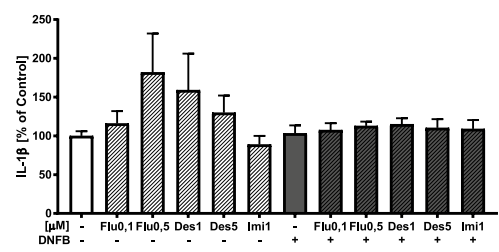

DNFB : Flu0,1Fluo,5 Des1 Des5 Imi1 : Flu0,1 Flu0,5 Des1 Des5 Imi1
Fig. 1 The effect of antidepressants on the level of IL-1 $\beta$ a, IL-6 b, CCL2 $\mathbf{c}$, and CXCL8 $\mathbf{d}$ produced by HaCaT cells after stimulation with LPS (left side), TNF- $\alpha /$ IFN- $\gamma$ (middle), and DNFB (right side). The level of cytokines was measured by ELISA after $24 \mathrm{~h}$ of incubation in medium from cell cultures as $\mathrm{pg} / \mathrm{ml}$ (except IL-1 $\beta$-lysates, measured in $\mathrm{pg} / \mathrm{mg}$ protein). Data presented (mean $\pm \mathrm{SEM}$ ) as $\%$ control and are derived from three different experiments, where 3 wells of cell culture were used for each group. ${ }^{*} p<0.05$ vs. control, $\# p<0.05$ vs. appropriate stimulated group. Flu, fluoxetine; Des, desipramine; Imi, imipramine; LPS, lipopolysaccharide; TNF/IFN, tumor necrosis factor (TNF)- $\alpha /$ interferon (IFN)- $\gamma$; DNFB, 2,4-dinitrofluorobenzene
DNFB stimulation significantly decreased the production of CCL2 by $\mathrm{HaCaT}$ cells $(p<0.05)$ and antidepressants did not have a significant effect on the CCL2 production (Fig. 1c).

The secretion of CXCL8 was significantly elevated by all stimulators of HaCaT cells $(p<0.05)$. TNF- $\alpha / \mathrm{IFN}-\gamma$ had the strongest stimulatory effect followed by LPS, while there was a slight increase after administration of DNFB. Antidepressants did not affect the normalization of this parameter after administration of the stimulatory factors (Fig. 1d).
There was no effect of the antidepressant drugs under basal conditions on either of the investigated pro-inflammatory factors (Fig. 1a-d).

\section{Effects of Antidepressant Drugs and LPS, TNF-a/ IFN- $y$, or DNFB Stimulation on ICAM-1 Expression in HaCaT Cells}

ICAM-1 protein expression level was determined with ELISA in lysates of $\mathrm{HaCaT}$ cells (24 h of incubation), and 
the expression level of mRNA using real-time PCR $(4 \mathrm{~h}$ of incubation) in both vehicle-treated control cultures and stimulant-treated cultures.

We observed a stimulatory effect of LPS on the ICAM-1 gene expression in $\mathrm{HaCaT}$ cells $(p<0.05)$ and found significantly decreased ICAM-1 mRNA expression after pretreatment with fluoxetine $(0.5 \mu \mathrm{M}, p<0.05)$, desipramine $(1 \mu \mathrm{M}, p<0.05)$, and imipramine $(1 \mu \mathrm{M}, p<0.05)$ (Fig. 2a). After the stimulation of the cells with LPS, an increase in ICAM-1 protein expression was observed $(p<0.05)$, although the antidepressants used herein did not significantly decrease ICAM-1 (Fig. 2b).

In the case of the TNF- $\alpha / \mathrm{IFN}-\gamma$ stimulation, keratinocytes dramatically enhanced the expression of ICAM-1 mRNA $(p<0.05)$. Furthermore, fluoxetine in a higher concentration $(0.5 \mu \mathrm{M}, p<0.05)$ and desipramine at both 1 and $5 \mu \mathrm{M}(p<0.05)$ reduced the stimulated mRNA expression of ICAM-1 (Fig. 2c). ICAM-1 protein expression was significantly elevated after the stimulation with TNF- $\alpha / \mathrm{IFN}-\gamma$ $(p<0.05)$ and pretreatment with antidepressant drugs did not significantly affect the stimulated ICAM-1 protein expression (Fig. 2d). These results were also replicated using confocal microscopy after staining the HaCaT cells with an antiICAM-1 antibody ( $1 \mathrm{~h}$ of incubation) (Fig. $2 \mathrm{~g}$ ).

The stimulation of HaCaT cells with DNFB increased the expression of ICAM-1 $(p<0.05)$. Furthermore, we demonstrated that fluoxetine $(0.1$ and $0.5 \mu \mathrm{M}, p<0.05)$ and desipramine $(1$ and $5 \mu \mathrm{M}, p<0.05)$ pretreatment effectively decreased the DNFB-induced upregulation of ICAM-1 mRNA levels (Fig. 2e). After DNFB stimulation, there was no significant effect of antidepressants on ICAM-1 protein levels (Fig. 2f).

\section{Effects of Antidepressant Drugs and LPS, TNF- $a$ / IFN- $y$, or DNFB Stimulation on the E-Cadherin Expression in HaCaT Cells}

In our study, both the 4-h incubation of keratinocytes with LPS and antidepressants had no effect on E-cadherin gene expression (Fig. 3a). LPS stimulation of cells decreased E-cadherin protein expression and fluoxetine $(0.1$ and $0.5 \mu \mathrm{M}, p<0.05)$ normalized the effects of LPS. We also observed a decrease in E-cadherin protein expression after treatment with desipramine $(5 \mu \mathrm{M}, p<0.05)$ and imipramine $(1 \mu \mathrm{M}, p<0.05)$ (Fig. 3b).

The effects of LPS stimulation and antidepressant drugs on the expression of E-cadherin on $\mathrm{HaCaT}$ keratinocytes were qualitatively confirmed by immunocytochemical staining using confocal microscopy (Fig. 3g).

There was no effect of the TNF- $\alpha / \mathrm{IFN}-\gamma$ stimulation (Fig. 3c, d) or DNFB stimulation (Fig. 3e, f) of HaCaT cells on E-cadherin levels, and both gene and protein expression. Pretreatment with antidepressants did not affect E-cadherin in stimulated cells.

\section{Effects of Antidepressant Drugs and LPS, TNF-a/ IFN- - , or DNFB Stimulation on the Activation of NF-kB and p-38 Pathway in HaCaT Cells}

To further investigate the intracellular mechanism underlying the anti-inflammatory effects of antidepressants in the stimulated $\mathrm{HaCaT}$ cell line, we assayed kinase activation. We found that LPS or TNF- $\alpha / \mathrm{IFN}-\gamma$ stimulation for $1 \mathrm{~h}$ activated p38 kinase. Pretreatment with antidepressant drugs showed no effect on the stimulant-evoked increase in phosphorylation of p38 kinase; however, under the influence of desipramine and imipramine, we observed a tendency to decrease the level of $\mathrm{p} 38$ in cultures stimulated with TNF- $\alpha /$ IFN- $\gamma$ and an increase in the level of the phosphorylated form of kinase p38 in LPS-stimulated cultures (Fig. 4d).

We observed a tendency to increase NIK kinase activation under the influence of LPS or TNF- $\alpha / \mathrm{IFN}-\gamma$ and a tendency to inhibit NIK kinase activation after using antidepressant drugs in a cell culture (Fig. 4c). Our results indicate that both under the influence of stimulants and various antidepressants, there are no significant effects on the phosphorylated form of IкB $\alpha$ (kappa B inhibitor) (Fig. 4a).

The use of DNFB in HaCaT keratinocyte cultures caused an increase in the level of the active form of the NF- $\mathrm{kB}$ p65 subunit, and tricyclic antidepressants tended to reduce the level of $\mathrm{p}-\mathrm{NF} \mathrm{FB}$ p65. LPS and TNF- $\alpha / \mathrm{IFN}-\gamma$ caused less phosphorylation of NF- $\mathrm{KB}$ p 65 and the use of antidepressants did not affect NF-kB p65 expression (Fig. 4b).

\section{Discussion}

The first major finding of this study is that antidepressants suppress some aspects of the inflammatory response in $\mathrm{HaCaT}$ keratinocytes. Imipramine, desipramine, and fluoxetine have beneficial anti-inflammatory effects as indicated by the diminished production of inflammatory factors and suppression of the inflammatory response. We found that after stimulation with LPS or TNF- $\alpha /$ IFN- $\gamma$, HaCaT keratinocytes synthesize significantly more IL- $1 \beta$ than unstimulated cells and that antidepressants significantly decrease IL- $1 \beta$ production in activated $\mathrm{HaCaT}$ cells. The IL- 1 family plays a leading role in the induction and elicitation of contact hypersensitivity in both animal models and humans as well (Mattii et al. 2013; Enk and Katz 1995). In mice, the application of the skin allergen increased the expression of IL-1 $\beta$ mRNA (Kermani et al. 2000). Furthermore, biopsy skin fragments from patients with ACD showed elevated IL-1 $\beta$, IL-33, IL-36 $\alpha$, IL-36 $\beta$, and IL-36 $\gamma$ mRNA expression (Mattii et al. 2013).

Previously, researchers observed that imipramine, clomipramine, and citalopram reduce IL- $1 \beta$ secretion by mitogen-stimulated monocytes (Xia et al. 1996). Furthermore, 

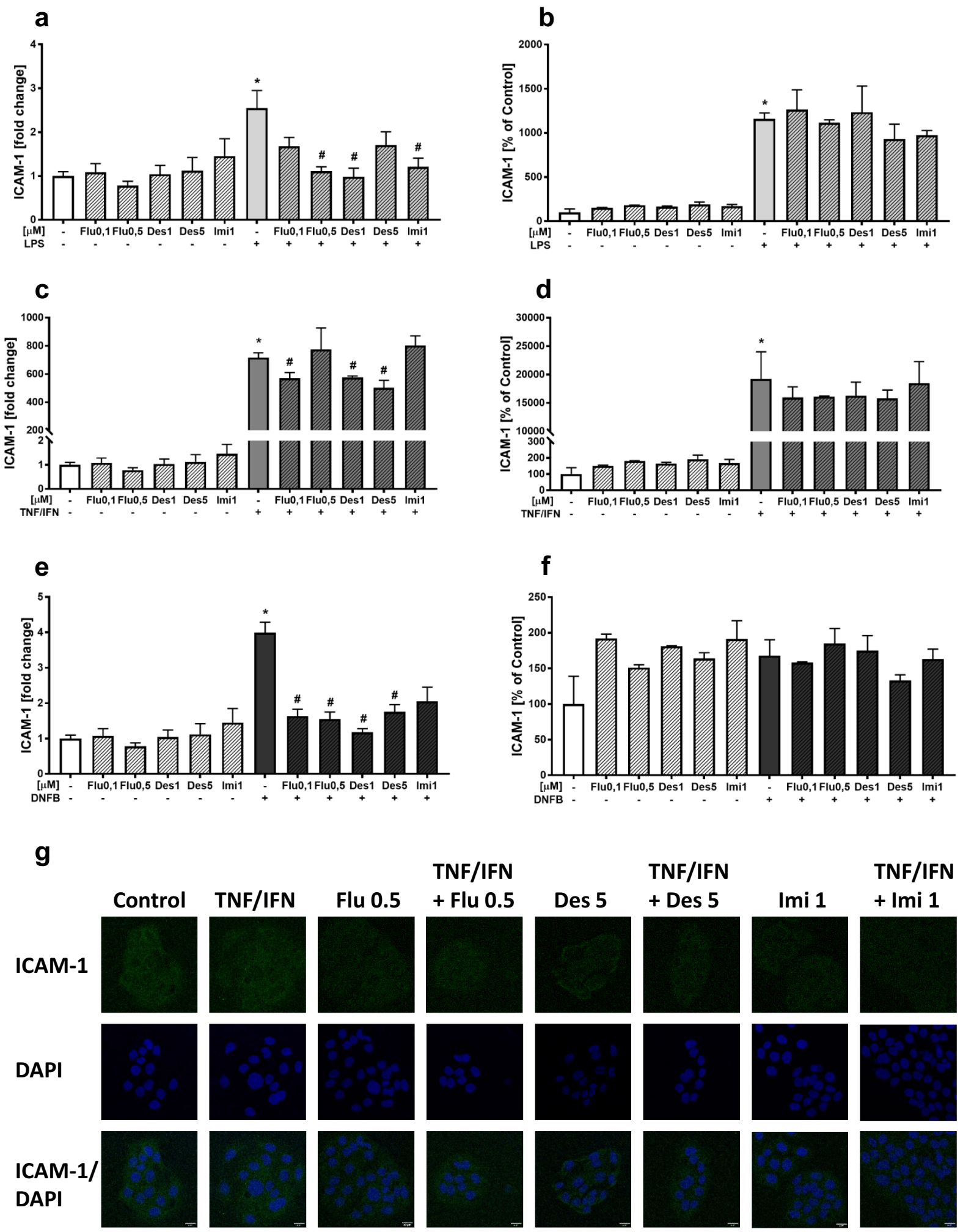

imipramine, fluoxetine (Obuchowicz et al. 2014), and tianeptine (Ślusarczyk et al. 2018) decrease IL-1 $\beta$ mRNA expression (also IL-18) and IL-1 $\beta$ production in LPS-stimulated microglia cultures. Dao-Ung et al. (2015) showed that paroxetine blocks the human $\mathrm{P} 2 \mathrm{X} 7$ receptor, which is activated during immunization with a hapten, leading to activation of nucleotide-binding oligomerization domain-like (NODlike) receptor pyrin-containing 3 inflammasome (NLRP3) inflammasome subunits and production of mature forms of IL-1 $\beta$ and IL-18 (Martin et al. 2008; Silvestre et al. 2018). 
4 Fig. 2 The effect of antidepressants on the gene expression of ICAM-1 (left panel; a, c, e) and the protein level of ICAM-1 (right panel; b, d, f) in HaCaT cells after stimulation with LPS, TNF- $\alpha$ / IFN- $\gamma$, and DNFB. The expression of ICAM-1 in cell lysates was determined after $4 \mathrm{~h}$ of incubation, and the results are presented as the mean fold change $( \pm$ SEM) relative to the reference gene (GAPDH). ICAM-1 protein level was assessed by ELISA after $24 \mathrm{~h}$ incubation; in cell culture lysates, the measurement was done in $\mathrm{pg} /$ mg protein, the averaged results are presented as \% control $( \pm$ SEM). The presented data come from three different experiments (for individual types of assays), where for each group, there were 3 wells of cell culture. $* p<0.05$ vs. control, $\# p<0.05$ vs. appropriate stimulated group. Representative fluorescence photomicrographs $\mathbf{g}$ showing the effect of TNF- $\alpha /$ IFN- $\gamma$ and antidepressants: fluoxetine (Flu, $0.5 \mu \mathrm{M}$ ), desipramine (Des, $5 \mu \mathrm{M}$ ), or imipramine (Imi, $1 \mu \mathrm{M}$ ) on ICAM-1 expression in HaCaT cells, incubated for $1 \mathrm{~h}$. The ICAM-1 signal was immunodetected using anti-human, staining with anti-CD54 PE (ICAM-1) antibody, and nuclei were stained using DAPI labeling. Scale bar $(20 \mu \mathrm{m})$ is located in the bottom right corner of each image. Flu, fluoxetine; Des, desipramine; Imi, imipramine; LPS, lipopolysaccharide; TNF/IFN, tumor necrosis factor (TNF)- $\alpha /$ interferon (IFN)- $\gamma$; DNFB, 2,4-dinitrofluorobenzene

We also reported that antidepressant drugs may reduce IL-1 $\beta$ release from mitogen-stimulated spleen cells isolated from rats under the chronic mild stress procedure (Kubera et al. 1996). However, recent meta-analyses have shown no effects of antidepressants on IL- $1 \beta$ levels in major depressed (MDD) patients (Köhler et al. 2018; Liu et al. 2020).

We also found that desipramine had an inhibitory effect on the release of IL- 6 in TNF- $\alpha / \mathrm{IFN}-\gamma$-stimulated cells, whereas fluoxetine did not have such effects on TNF- $\alpha /$ IFN- $\gamma /$ DNFB-stimulated cells and even stimulated IL- 6 in LPS-stimulated keratinocytes. There is now evidence that IL-6 is elevated in MDD patients, although antidepressants may increase (Maes et al. 1997; Kubera et al. 2000, 2004; Fornaro et al. 2011) or decrease (Xia et al. 1996; Himmerich et al. 2010; Köhler et al. 2018; Duda et al. 2019) serum IL-6 levels. Previous studies in animals showed that fluoxetine and desipramine treatment increased the secretion of IL- 6 by splenocytes in response to mitogen stimulation (Curzytek et al. 2013). However, the use of both drugs in animals subjected to contact sensitization resulted in a decrease in its secretion by spleen cells. In addition, the level of IL-6 release was not regulated by antidepressants and/or CHS in stimulated lymph node cells (Curzytek et al. 2013) or splenocytes (Kubera et al. 2012). The increase in IL-6 production by keratinocytes may be a compensatory response as indicated, for example, by a significant inverse association between increased IL- 6 and decreased TNF- $\alpha$, cytokines that are activated in the early phase of CHS (Flint et al. 1998). In addition, recent research indicates that the anti-inflammatory potential of IL-6 may proceed through the membrane IL-6R $\alpha$ receptor, which is present in keratinocytes (Frempah et al. 2019).

The second major finding of this study is that stimulated $\mathrm{HaCaT}$ keratinocytes exhibit an increased production of chemokines and that antidepressants may modulate some but not all chemokine levels. First, activation with LPS or TNF- $\alpha /$ IFN- $\gamma$ increased the synthesis of CCL2 (monocyte chemoattractant protein-1; MCP-1), and fluoxetine, desipramine, and imipramine decreased the stimulated production of CCL2. CCL2 plays a leading role in the elicitation phase of CHS, through increased production by skin residing cells (keratinocytes, fibroblasts, endothelial cells), followed by infiltration of monocytes and lymphocytes. This chemokine appears rapidly and its high concentrations persist for many hours after exposure to a hapten (Goebeler et al. 2001). Transgenic mice overexpressing CCL2 react to immunization with a DNFB-enhanced inflammatory response and greater infiltration of dendritic cells into the skin. Importantly, lowering the level of this chemokine resulted in the attenuation of the CHS-induced reaction (Mizumoto et al. 2001). Furthermore, overexpression of CCL2 in the course of CHS in mice caused an increase in itching and pain that accompany this disease (Jiang et al. 2019). Few studies reported on the impact of antidepressants on chemokine levels. For example, in a murine model of sepsis, amitriptyline decreased the serum levels of CCL2 and CXCL1 (KC, keratinocyte-derived chemokine) (Xia et al. 2019). In the brain of prenatally stressed rats, the therapeutic potential of antidepressants, including tianeptine, venlafaxine, and fluoxetine, is associated with regulatory activities targeted at CXCL12, and CX3CL1 and their CX3CR1, CXCR4, and CXCR7 receptors (Trojan et al. 2017). Moreover, tianeptine administration may reduce the level of CCL2 in LPS-stimulated microglia cultures (Ślusarczyk et al. 2018). O'Sullivan et al. (2010) observed that single intraperitoneal administrations of desipramine and atomoxetine (both noradrenaline reuptake inhibitors) to rats inhibited the LPS-increased expression of CCL5 (RANTES, regulated on activation, normal $\mathrm{T}$ cell expressed and secreted) and CXC10 (IP-10) mRNA in the frontal cortex, hippocampus, and spleen. Other authors showed that atomoxetine and desipramine increased CCL2 secretion in primary astrocyte cultures (Hinojosa et al. 2011). In MDD patients, treatment with antidepressants decreased (Köhler et al. 2018) or did not affect serum CCL2 levels (Ho et al. 2017).

However, chemokines exert a Janus-faced activity whereby initial increased concentrations stimulate the influx of macrophages and monocytes toward the site of inflammation, whereas in a later stage, the same chemokines may drive the influx of $\mathrm{T}$ regulatory cells which may inhibit the hypersensitivity reaction. Therefore, blocking the release of these chemokines may attenuate both inflammatory and regulatory mechanisms. Interestingly, the use of DNFB alone inhibits CCL2 secretion in keratinocytes and the antidepressants do not normalize this effect. Other authors, who investigated the effects of DNCB or TNCB on CCL2 gene expression in the skin of mice, did not observe any differences 

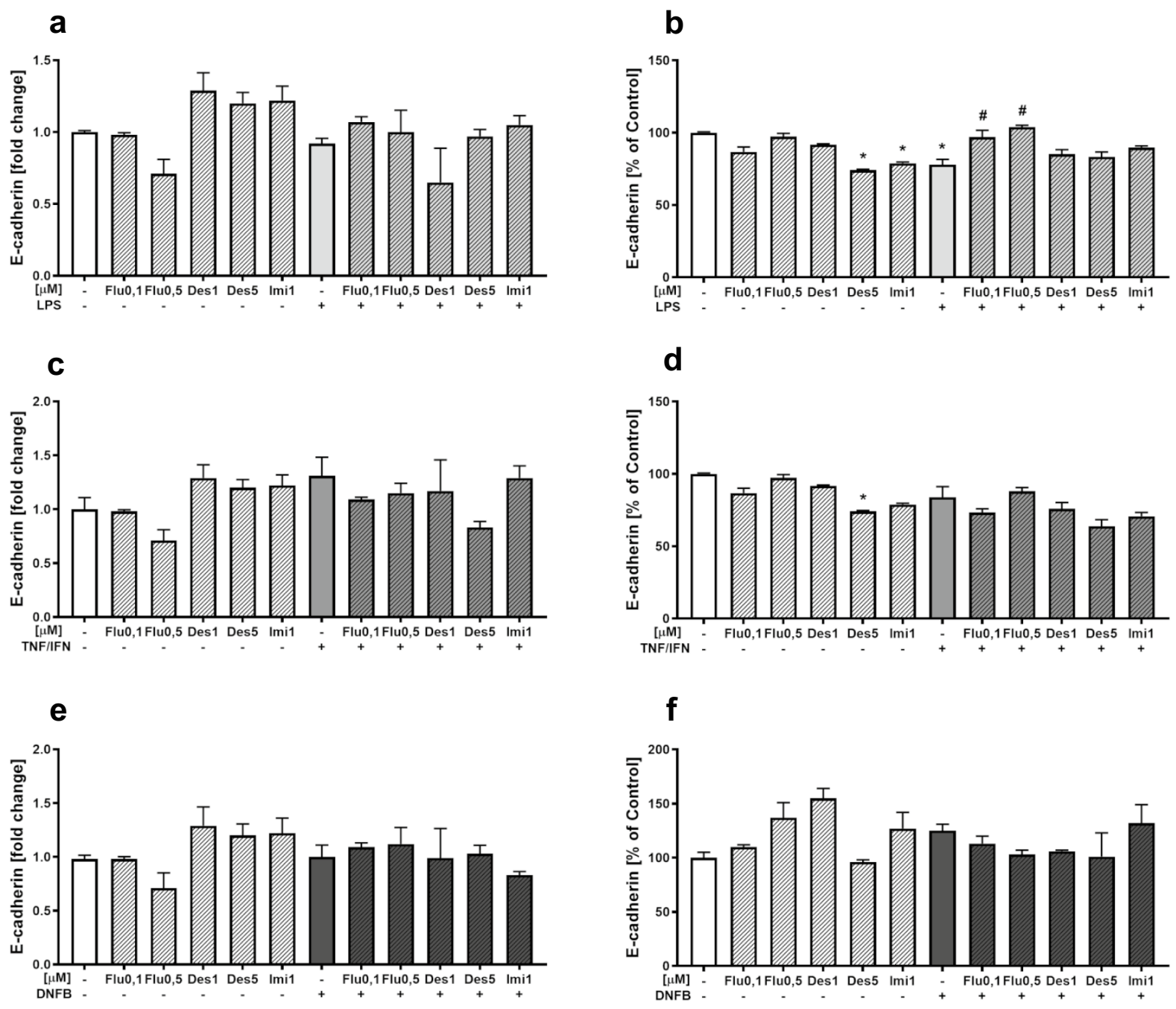

g

LPS

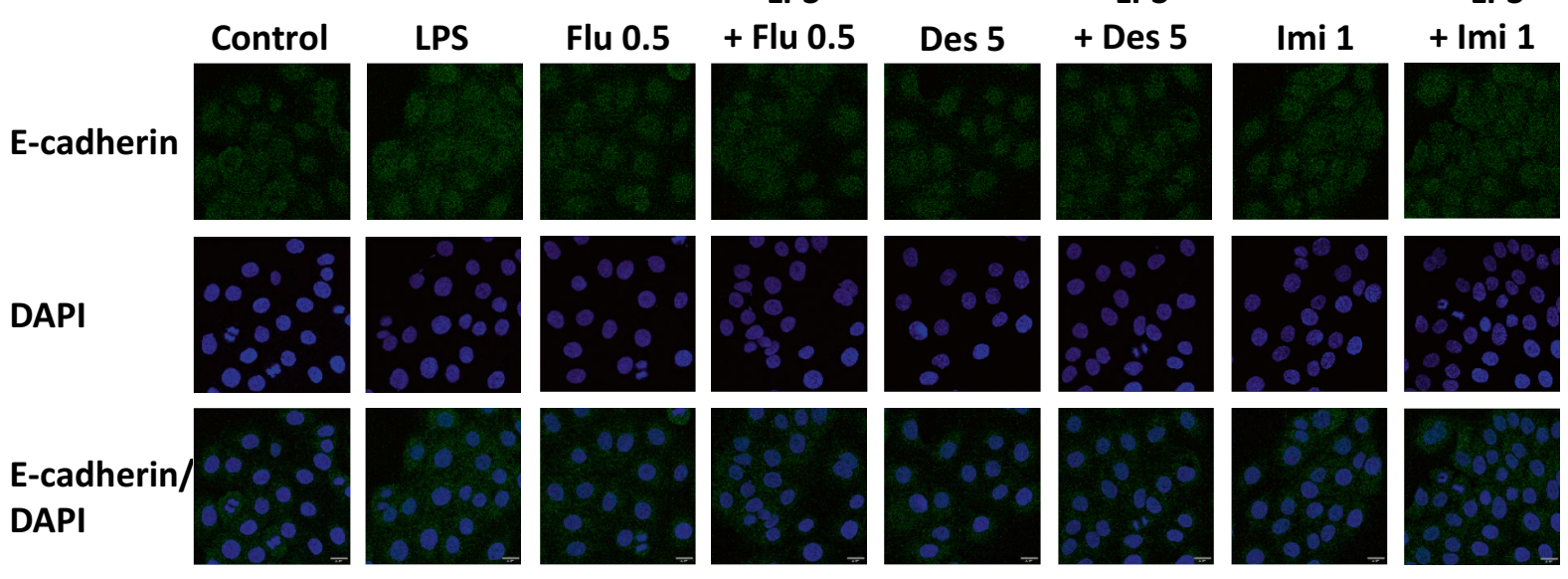

in the level of CCL2 mRNA in the sensitized mice group compared to the control groups (Chen et al. 2020; Gautam et al. 1994). Haptens increased mRNA synthesis of CCL2 in fibroblast cells and the extracellular matrix of dermal collagen (Gautam et al. 1994). Perhaps the presence of DNFB inhibits the CCL2 O-glycosylation process in HaCaT cells which shortens the half-life of the CCL2 protein (hence the decrease in CCL2 levels observed after $24 \mathrm{~h}$ of DNFB 
4Fig. 3 The effect of antidepressants on the gene expression of E-cadherin (left panel; a, c, e) and the protein level of E-cadherin (right panel; b, d, f) in HaCaT cells after stimulation with LPS, TNF- $\alpha /$ IFN- $\gamma$, and DNFB. The expression of E-cadherin in cell lysates was determined after $4 \mathrm{~h}$ of incubation, and the results are presented as the mean fold change $( \pm$ SEM) relative to the reference gene $(\mathrm{GAPDH})$. E-cadherin protein level was assessed by ELISA after $24 \mathrm{~h}$ of incubation; in cell culture lysates, the measurement was done in $\mathrm{pg} / \mathrm{mg}$ protein, the averaged results are presented as $\%$ of control $( \pm$ SEM $)$. The presented data come from three independent experiments (for individual types of assays), where for each group, there were 3 wells of cell culture. ${ }^{*} p<0.05$ vs. control, $\# p<0.05$ vs. LPS-stimulated group. Representative fluorescence photomicrographs (g) showing the effect of LPS and antidepressants: fluoxetine (Flu, $0.5 \mu \mathrm{M}$ ), desipramine (Des, $5 \mu \mathrm{M}$ ), or imipramine (Imi, $1 \mu \mathrm{M}$ ) on E-cadherin expression in HaCaT cells, incubated for $24 \mathrm{~h}$. The E-cadherin signal was immunodetected using anti-human, staining with anti-E-cadherin FITC antibody, and nuclei were stained using DAPI labeling. The scale bar $(20 \mu \mathrm{m})$ is located in the bottom right corner of each image. Flu, fluoxetine; Des, desipramine; Imi, imipramine; LPS, lipopolysaccharide; TNF/ IFN, tumor necrosis factor (TNF)- $\alpha /$ interferon (IFN)- $\gamma$; DNFB, 2,4-dinitrofluorobenzene

stimulation) but increases the bioactivity of this chemokine (Ruggiero et al. 2003).

We observed that keratinocyte stimulants increased the secretion of CXCL8 (IL-8) and that antidepressants did not reduce CXCL8 secretion by stimulated keratinocytes. During contact sensitization to picryl chloride in mice, an increase in the synthesis of CXCL1, CXCL2, and CXCL5 (homologous to CXCL8) was observed (Sakai et al. 2019), whereas nickel allergy was associated with a decrease in CXCL8 in humans (Summer et al. 2018). In patients suffering from MDD, antidepressants did not affect peripheral levels of CXCL8 (Köhler et al. 2018; Liu et al. 2020).

The third important finding of this study is that various stimulants (especially TNF- $\alpha / \mathrm{IFN}-\gamma$ ) may increase the production of ICAM- 1 in HaCaT cells and that antidepressants decrease ICAM-1 mRNA expression in stimulated cell cultures. ICAM-1 plays a key role in CHS because a lack of ICAM-1 inhibits DNFB-induced CHS (Ogawa et al. 2010). Likewise, the use of anti-ICAM-1 or anti-LFA-1 (ICAM-1 ligand) antibodies inhibits the rolling process and migration of $\mathrm{T}$ lymphocytes to local lymph nodes during an ongoing inflammatory response (Teijeira et al. 2017). Moreover, tolerance to low doses of allergens applied to the skin of mice was associated with the abolition of elevated ICAM-1 expression in the effector phase of the CHS reaction (Komura et al. 2009). We observed that all antidepressants lowered ICAM-1 gene expression. Other researchers observed that a single, intraperitoneal administration of atomoxetine or desipramine to LPS-treated Sprague Dawley rats inhibited LPS-induced ICAM-1 mRNA expression in the frontal cortex, hippocampus, and spleen of experimental animals (O'Sullivan et al. 2010). Mirtazapine administered in a mouse model of autoimmune hepatitis induced a decrease in the levels of many pro-inflammatory factors, including ICAM-1 in the liver (Almishri et al. 2019). Fluoxetine, administered for 3 weeks to rats with induced pulmonary arterial hypertension, decreased ICAM-1 protein expression in lung tissues ( $\mathrm{Li}$ et al. 2011). The opposite effect was observed in a fluoxetine-treated (for 4 weeks) mouse model of atherosclerosis, which showed an increased expression of ICAM-1 on neutrophils and monocytes, but not endothelial cells (Rami et al. 2018).

We found that antidepressants also modulate the expression of E-cadherin in stimulated $\mathrm{HaCaT}$ cell cultures. These antidepressants did not affect E-cadherin gene expression, whereas desipramine and imipramine reduced E-cadherin protein levels and only fluoxetine normalized the LPSreduced expression of this adhesive molecule. This normalizing effect of fluoxetine on the impaired expression of E-cadherin may suggest that this drug has efficacy in maintaining integrity or tissue homeostasis. On the other hand, the reduced expression of E-cadherin may be associated with the weakening of the skin barrier, thereby promoting allergic reactions, a phenomenon which is occasionally observed in patients exposed to antidepressants (Beer 1994; SanzGallén et al. 2011; Doffoel-Hantz et al. 2009; Gillet-Terver et al. 1996; Lin et al. 2009). Adverse effects of fluoxetine were also observed in pancreatic $\beta$ cells, with incubation of murine cell line MIN6 with fluoxetine being accompanied by impairment of cell function (Chang et al. 2017). Moreover, the reduction in E-cadherin levels on tumor cells is associated with the formation of metastases (Cavallaro and Christofori 2001). In our previous studies, we showed that desipramine and fluoxetine significantly increase the likelihood of metastases to the spleen, liver, skin, gastrointestinal tract, and peritoneal cavity in mice with skin melanoma induced by B16F10 tumor cell implantation (Kubera et al. 2011a).

Regulation of expression of adhesion molecule ICAM-1 plays an important role in both the induction and elicitation of contact hypersensitivity response. Under physiological conditions, the increased expression of ICAM-1 facilitates the rolling, adhesion, and endothelial transmigration of effector $\mathrm{T}$ cells to sites of inflammation and therefore influences the magnitude of the inflammatory process at the site (Harjunpää et al. 2019). Cadherins represent a large family of glycoproteins associated with the cell membrane. They are involved in the calcium-dependent regulation of cell adhesion, regulate the morphogenesis of tissue, and are responsible for the maintenance of tissue continuity and coordination of the movement of the cells (Van den Bossche and Van Ginderachter 2013). The expression of E-cadherin on the surface of keratinocytes not only allows to maintain the tight junctions between the cells forming the epidermis but also constitutes a "mechanical trap" for the resident dendritic cells in the skin. Decreased expression of E-cadherin on the surface of dendritic cells and keratinocytes under 

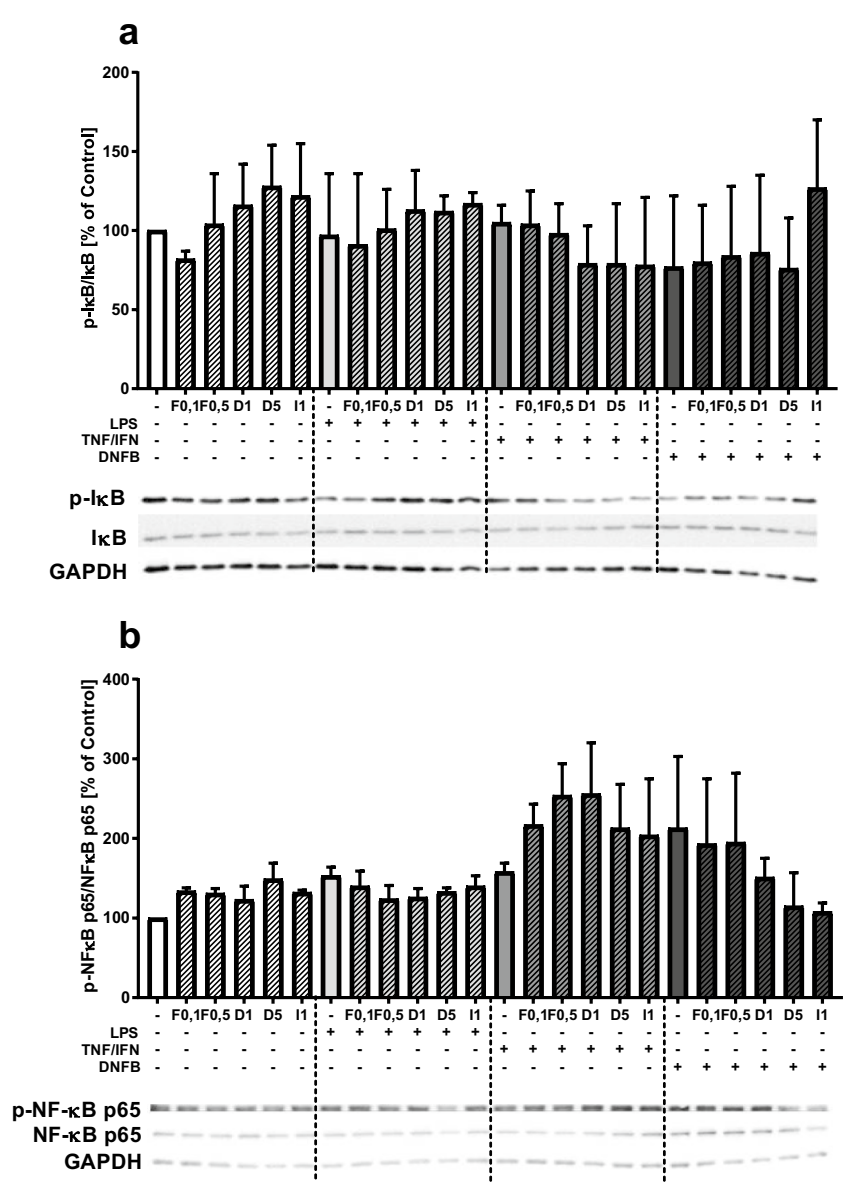

Fig. 4 The effect of antidepressants and stimulation on the level

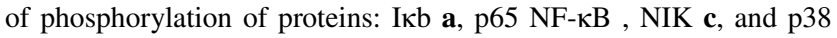
d in $\mathrm{HaCaT}$ cells. Protein levels were assessed by Western blotting in samples incubated for $1 \mathrm{~h}$. Histograms show band density normalized to the reference protein, averaged (from 3 different experiments),

the influence of inflammatory factors is necessary for the migration of dendritic cells into the lymph nodes (Brand et al. 2019). Proper cell adhesion is essential for maintaining homeostasis and correct functioning of cells and tissues. Therefore, our findings showing that antidepressants may normalize the expression of ICAM- 1 and E-cadherin in HaCaT keratinocytes may partly explain their anti-inflammatory action.

The effectiveness of antidepressants in inhibiting ICAM-1 was observed in mRNA expression, but not in the protein level. This difference may be due to different kinetics of expression of the ICAM-1 gene and protein. Likewise, in endothelial cells stimulated with IL- $1 \beta$, IFN- $\gamma$, and TNF$\alpha$, the maximum ICAM-1 mRNA expression was observed after $4 \mathrm{~h}$ of incubation and a decrease in expression after $7 \mathrm{~h}$, whereas ICAM-1 protein levels were continuously increased in the stimulated cell culture, 1 to $24 \mathrm{~h}$ later (Barton et al. 1995). HaCaT cell stimulation led to a tremendous increase
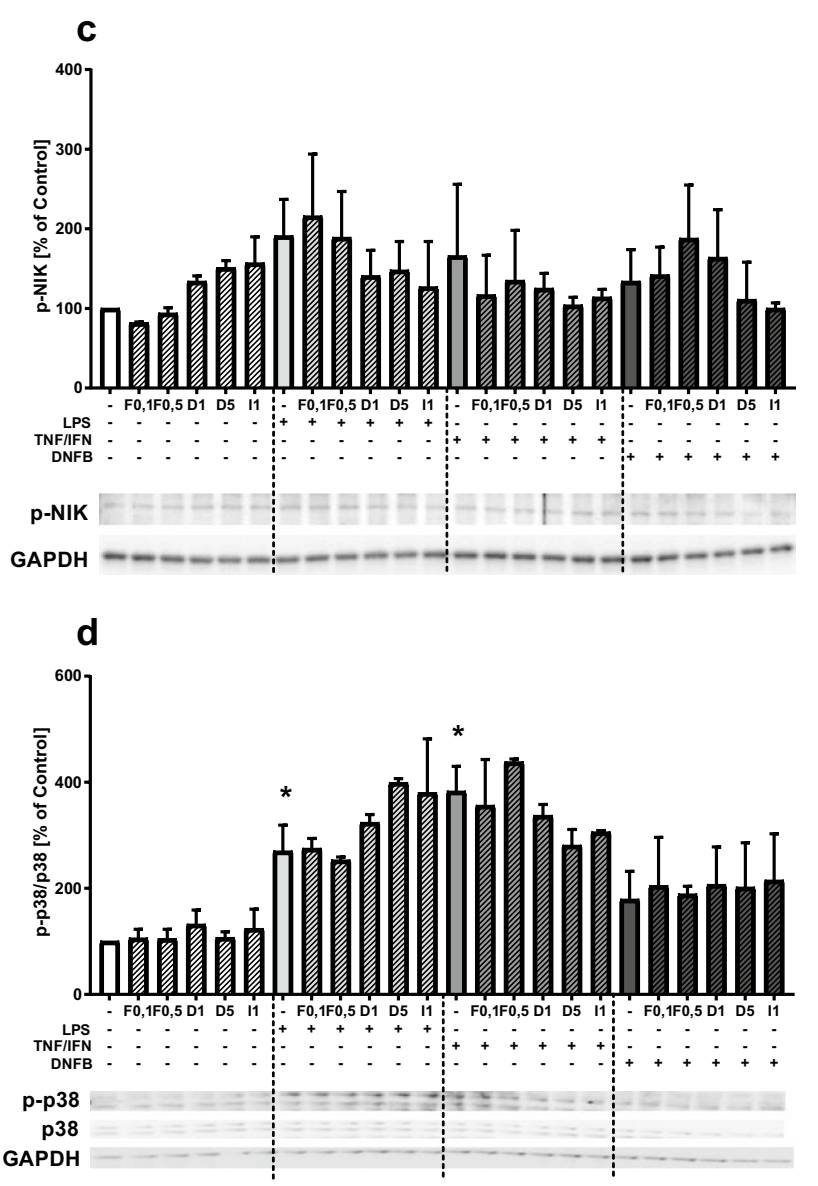

and presented as $\%$ of control \pm SEM, with representative immunoblots. ${ }^{*} p<0.05$ vs. control group. F, fluoxetine; D, desipramine; I, imipramine; LPS, lipopolysaccharide; TNF/IFN, tumor necrosis factor (TNF)- $\alpha /$ interferon (IFN)- $\gamma$; DNFB, 2,4-dinitrofluorobenzene

in ICAM-1 mRNA, and the inhibitory effect of antidepressants on ICAM-1 gene expression was observed at the time of maximum expression. We did not observe a statistically significant inhibitory effect of antidepressants on the increase of ICAM-1 protein levels stimulated with LPS or TNF- $\alpha / \mathrm{IFN}-\gamma$, despite the decrease in mRNA expression (Fig. 2).

Interestingly, patients with depression have increased ICAM-1 levels in serum (Dimopoulos et al. 2006) and the dorsolateral prefrontal cortex (Thomas et al. 2000). Moreover, it is suggested that antidepressant efficacy may be explained by regulating neuronal cell adhesion molecule (NCAM) (Wedzony et al. 2013). Such effects may also explain that antidepressants may have inhibitory effects on contact hypersensitivity in animal models, as we previously investigated (Kubera et al. 2012; Curzytek et al. 2013, 2015). 
The fourth finding of this study is that the stimulation of LPS and TNF- $\alpha / \mathrm{IFN}-\gamma$ activated p38 kinase while there were no significant effects on the other signaling pathways assayed here. There were no significant effects of antidepressants and only trends toward significant effects were observed. Few studies show that contact hypersensitivity reactions are accompanied by NF- $\mathrm{KB}$ and MAP kinase activation in keratinocytes, dendritic cells, and $\mathrm{T}$ cells (Bell et al. 2003; Ritprajak et al. 2012; Galbiati et al. 2011; Honda et al. 2013; Martin et al. 2008). Antidepressant drugs decrease the activation of NF- $\mathrm{KB}$ and MAP kinases in animal models of depression (Obuchowicz et al. 2014; Yang et al. 2014; Roumestan et al. 2007), although there are also negative reports (Martín-Hernández et al. 2018). Previous data indicate that the anti-inflammatory effects of antidepressants are at least in part attributable to their ability to regulate the p38 kinase signal transduction pathway whereby the activation of $\mathrm{p} 38$ is associated with increased expression of the serotonin transporter, which is targeted by antidepressants (Haroon et al. 2012).

$\mathrm{HaCaT}$ cells also express antidepressant metabolizing enzymes, although the metabolism of drugs in the skin is about 300-fold lower than in the liver (Kazem et al. 2019). However, it cannot be excluded that the anti-inflammatory effect of antidepressants on the inflamed $\mathrm{HaCaT}$ cell line may be explained by active drug metabolites.

In summary, the antidepressant drugs examined in our study effectively inhibited the stimulated secretion of proinflammatory cytokines, chemokines, and modulated the expression of adhesion molecules by the keratinocyte cell line HaCaT. Therefore, antidepressants may have some clinical efficacy in patients with ACD and especially in patients with comorbid depression and contact allergy. Our results show the beneficial role of antidepressants in ameliorating the pro-inflammatory responses in keratinocytes and the ability of antidepressant drugs to reduce peripheral inflammation induced by inflamed keratinocytes. The results of our study show that keratinocytes may contribute to the general immune-inflammatory response and, consequently, may affect neuroinflammation and microglial activation in the central nervous system.

Acknowledgements We are greatly thankful to Julita Wesołowska for her technical help with microscope imaging.

Author Contribution $\mathrm{KC}$ collected the samples and carried out biochemical experiments. $\mathrm{KC}$ analyzed all the data with supervision from MK. KC and MK wrote the manuscript. MM contributed to the final manuscript preparation. All authors revised the paper critically for intellectual content and gave final approval of the version to be published.

Funding This work was supported by grant no. 2014/13/N/NZ6/00639 (PRELUDIUM), National Science Centre, Poland.
Open Access This article is licensed under a Creative Commons Attribution 4.0 International License, which permits use, sharing, adaptation, distribution and reproduction in any medium or format, as long as you give appropriate credit to the original author(s) and the source, provide a link to the Creative Commons licence, and indicate if changes were made. The images or other third party material in this article are included in the article's Creative Commons licence, unless indicated otherwise in a credit line to the material. If material is not included in the article's Creative Commons licence and your intended use is not permitted by statutory regulation or exceeds the permitted use, you will need to obtain permission directly from the copyright holder. To view a copy of this licence, visit http://creativecommons.org/licenses/by/4.0/.

\section{References}

Almishri W, Shaheen AA, Sharkey KA, Swain, MG (2019) The antidepressant mirtazapine inhibits hepatic innate immune networks to attenuate immune-mediated liver injury in mice. Front Immunol 10 (APR): 1-14. https://doi.org/10.3389/fimmu.2019.00803

Aye A, Song YJ, Jeon YD, Jin JS (2020) Xanthone suppresses allergic contact dermatitis in vitro and in vivo. Int Immunopharmacol 78 (September 2019): 106061. https://doi.org/10.1016/j.intimp.2019. 106061

Barton WW, Wilcoxen S, Christensen PJ, Paine R (1995) Disparate cytokine regulation of ICAM-1 in rat alveolar epithelial cells and pulmonary endothelial cells in vitro. Am J Physiol Lung Cell Mol Physiol 269 (1 13-1). https://doi.org/10.1152/ajplung.1995.269.1. 1127

Beer K (1994) Fluoxetine-induced hypersensitivity. Arch Dermatol 130(6):803. https://doi.org/10.1001/archderm.1994.01690060141027

Bell S, Degitz K, Quirling M, Jilg N, Page S, Brand K (2003) Involvement of NF-KB signalling in skin physiology and disease. Cell Signal 15(1):1-7. https://doi.org/10.1016/S0898-6568(02) 00080-3

Blauvelt A, Hwang ST, Udey MC (2003) 11. Allergic and immunologic diseases of the skin. Journal of Allergy and Clinical Immunology 111(2 SUPPL. 2):560-570. https://doi.org/10.1067/mai.2003.78

Van den Bossche J, Van Ginderachter JA (2013) E-cadherin: from epithelial glue to immunological regulator. Eur J Immunol 43(1):34 37. https://doi.org/10.1002/eji.201243168

Brand A, Diener N, Zahner SP, Tripp C, Backer RA, Karram K, Jiang A, Mellman I, Stoitzner P, Clausen BE (2019) E-cadherin is dispensable to maintain langerhans cells in the epidermis. J Invest Dermatol. https://doi.org/10.1016/j.jid.2019.06.132

Cavallaro U, Christofori G (2001) Cell adhesion in tumor invasion and metastasis: loss of the glue is not enough. Biochim Biophys Acta Rev Cancer 1552(1):39-45. https://doi.org/10.1016/S0304419X(01)00038-5

Chang HY, Chen SL, Shen MR, Kung ML, Chuang LM, Chen YW (2017) Selective serotonin reuptake inhibitor, fluoxetine, impairs E-cadherin-mediated cell adhesion and alters calcium homeostasis in pancreatic beta cells. Sci Rep 7(1):1-13. https://doi.org/10. 1038/s41598-017-03747-0

Chen X, Lin J, Liang Q, Chen X, Zhongping Wu (2020) Pseudoephedrine alleviates atopic dermatitis-like inflammatory responses in vivo and in vitro. Life Sci 258(April):118139. https://doi.org/ 10.1016/j.lfs.2020.118139

Chen Y, Lyga J (2014) Brain-skin connection: stress, inflammation and skin aging. Inflammation and Allergy - Drug Targets 13(3):177190. https://doi.org/10.2174/1871528113666140522104422

Choi JK, Hyun Mee Oh, Lee S, Park JW, Khang D, Lee SW, Lee WS, Rho MC, Kim SH (2013) Oleanolic acid acetate inhibits atopic dermatitis and allergic contact dermatitis in a murine model. 
Toxicol Appl Pharmacol 269(1):72-80. https://doi.org/10.1016/j. taap.2013.03.001

Curzytek K, Kubera M, Majewska-Szczepanik M, Szczepanik M, Marcińska K, Ptak W, Duda W et al (2013) Inhibition of 2,4dinitrofluorobenzene-induced contact hypersensitivity reaction by antidepressant drugs. Pharmacol Rep. https://doi.org/10.1016/ S1734-1140(13)71481-6

Curzytek K, Kubera M, Majewska-Szczepanik M, Szczepanik M, Ptak W, Duda W, Leśkiewicz M et al (2015) Inhibitory effect of antidepressant drugs on contact hypersensitivity reaction is connected with their suppressive effect on NKT and CD8+T cells but not on TCR delta T cells. Int Immunopharmacol. https://doi.org/10. 1016/j.intimp.2015.08.001

Dąbrowska AK, Spano F, Derler S, Adlhart C, Spencer ND, Rossi RM (2018) The relationship between skin function, barrier properties, and body-dependent factors. Skin Res Technol 24(2):165-174. https://doi.org/10.1111/srt.12424

Dalgard FJ, Gieler U, Tomas-Aragones L, Lien L, Poot F, Jemec GBE, Misery L et al (2015) The psychological burden of skin diseases: a cross-sectional multicenter study among dermatological out-patients in 13 European countries. J Investig Dermatol 135(4):984-991. https://doi.org/10.1038/jid.2014.530

Dao-Ung P, Skarratt KK, Fuller SJ, Stokes L (2015) Paroxetine suppresses recombinant human P2X7 responses. Purinergic Signalling 11(4):481-490. https://doi.org/10.1007/s11302-015-9467-2

Diepgen TL, Weisshaar E (2007) Contact dermatitis: epidemiology and frequent sensitizers to cosmetics. J Eur Acad Dermatol Venereol 21(SUPPL. 2):9-13. https://doi.org/10.1111/j.1468-3083.2007. 02381.x

Dimopoulos N, Piperi C, Salonicioti A, Mitsonis C, Liappas I, Lea RW, Kalofoutis A (2006) Elevation of plasma concentration of adhesion molecules in late-life depression. Int J Geriatr Psychiatry 21(10):965-971. https://doi.org/10.1002/gps.1592

Doffoel-Hantz V, Boulitrop-Morvan C, Sparsa A, Bonnetblanc JM, Dalac S, Bédane C (2009) Photosensitivity associated with selective serotonin reuptake inhibitors. Clin Exp Dermatol 34(8):763765. https://doi.org/10.1111/j.1365-2230.2009.03484.x

Dubois T, Reynaert C, Jacques D, Lepiece B, Patigny P, Zdanowicz $\mathrm{N}$ (2018) 'Immunity and psychiatric disorders: variabilities of immunity biomarkers are they specific?' In Psychiatria Danubina, 30:S447-51. Psychiatr Danub

Duda W, Curzytek K, Kubera M, Connor TJ, Fagan EM, Basta-Kaim A, Lason W (2019) Interaction of the immune-inflammatory and the kynurenine pathways in rats resistant to antidepressant treatment in model of depression. Int Immunopharmacol 73 (May 2018): 527-38. https://doi.org/10.1016/j.intimp.2019.05.039

Enk AH, Katz SI (1995) Contact sensitivity as a model for T-cell activation in skin. J Invest Dermatol 105(1 Suppl):80S-83S

Farzanfar D, Dowlati Y, French LE, Lowes MA, Alavi A (2018) Inflammation: a contributor to depressive comorbidity in inflammatory skin disease. Skin Pharmacology and Physiology 31(5):246-251. https://doi.org/10.1159/000490002

Faugere M, Micoulaud-Franchi JA, Faget-Agius C, Lançon C, Cermolacce M, Richieri R (2018) High C-reactive protein levels are associated with depressive symptoms in schizophrenia. J Affect Disord 225 (September 2017): 671-75. https://doi.org/10.1016/j. jad.2017.09.004

Flint MS, Dearman RJ, Kimber I, Hotchkiss SAM (1998) Production and in situ localization of cutaneous tumour necrosis factor $\alpha(\mathrm{TNF}-\alpha)$ and interleukin 6 (IL-6) following skin sensitization. Cytokine 10(3):213-219. https://doi.org/10.1006/cyto.1997.0278

Fornaro M, Martino M, Battaglia F, Colicchio S, Perugi G (2011) Increase in IL-6 levels among major depressive disorder patients after a 6-week treatment with duloxetine $60 \mathrm{Mg} /$ Day: a preliminary observation. Neuropsychiatr Dis Treat 7(1):51-56. https:// doi.org/10.2147/NDT.S16382
Frempah B, Luckett-Chastain LR, Calhoun KN, Gallucci RM (2019) Keratinocyte-specific deletion of the IL-6RA exacerbates the inflammatory response during irritant contact dermatitis. Toxicology 423(June):123-131. https://doi.org/10.1016/j.tox.2019.05.015

Galbiati V, Mitjans M, Lucchi L, Viviani B, Galli CL, Marinovich M, Corsini E (2011) Further development of the NCTC 2544 IL-18 assay to identify in vitro contact allergens. Toxicol In Vitro 25(3):724-732. https://doi.org/10.1016/j.tiv.2010.12.011

Gautam S, Battisto J, J a Major, D Armstrong, M Stoler, and T a Hamilton. (1994) Chemokine expression in trinitrochlorobenzene-mediated contact hypersensitivity. J Leukoc Biol 55(4):452-460

Gillet-Terver MN, Modiano P, Tréchot P, Barbaud A, Schmutz JL (1996) Fluvoxamine photosensitivity. Australas J Dermatol 37(1):62-62. https://doi.org/10.1111/j.1440-0960.1996.tb01002.x

Goebeler M, Trautmann A, Voss A, Bröcker EB, Toksoy A, Gillitzer R (2001) Differential and sequential expression of multiple chemokines during elicitation of allergic contact hypersensitivity. Am J Pathol 158(2):431-440. https://doi.org/10.1016/S0002-9440(10)63986-7

Harjunpää H, Llort Asens M, Guenther C, Fagerholm SC (2019) Cell adhesion molecules and their roles and regulation in the immune and tumor microenvironment. Front Immunol 10 (MAY). https:// doi.org/10.3389/fimmu.2019.01078

Haroon E, Raison CL, Miller AH (2012) Psychoneuroimmunology meets neuropsychopharmacology: translational implications of the impact of inflammation on behavior. Neuropsychopharmacology 37(1):137-162. https://doi.org/10.1038/npp.2011.205

Himmerich H, Milenović S, Fulda S, Plümäkers B, Sheldrick AJ, Michel TM, Kircher T, Rink L (2010) Regulatory T cells increased while IL-1 $\beta$ decreased during antidepressant therapy. J Psychiatr Res 44(15):1052-1057. https://doi.org/10.1016/j. jpsychires.2010.03.005

Hinojosa AE, García-Bueno B, Leza JC, Madrigal JLM (2011) Regulation of CCL2/MCP-1 production in astrocytes by desipramine and atomoxetine: involvement of $\mathrm{A} 2$ adrenergic receptors. Brain Res Bull 86(5-6):326-333. https://doi.org/10.1016/j.brainresbull. 2011.09.014

Ho PS, Yen CH, Chen CY, Huang SY, Liang CS (2017) Changes in cytokine and chemokine expression distinguish dysthymic disorder from major depression and healthy controls. Psychiatry Res 248(60):20-27. https://doi.org/10.1016/j.psychres.2016.12.014

Honda T, Egawa G, Grabbe S, Kabashima K (2013) Update of immune events in the murine contact hypersensitivity model: toward the understanding of allergic contact dermatitis. J Investig Dermatol 133(2):303-315. https://doi.org/10.1038/jid.2012.284

Jiang H, Cui H, Wang T, Shimada SG, Sun R, Tan Z, LaMotte RH (2019) 'CCL2/CCR2 signaling elicits itch- and pain-like behavior in a murine model of allergic contact dermatitis'. Brain Behav Immun 80 (December 2018): 464-73. https://doi.org/10.1016/j. bbi.2019.04.026

Kazem S, Linssen EC, Gibbs S (2019) Skin metabolism phase I and phase II enzymes in native and reconstructed human skin: a short review. Drug Discovery Today 24(9):1899-1910. https://doi.org/ 10.1016/j.drudis.2019.06.002

Kermani F, Flint MS, Hotchkiss SAM (2000) Induction and localization of cutaneous interleukin-1 $\beta$ MRNA during contact sensitization. Toxicol Appl Pharmacol 169(3):231-237. https://doi.org/10. 1006/taap.2000.9085

Kimber I, Dearman RJ (2002) Allergic contact dermatitis: the cellular effectors. Contact Dermatitis 46(1):1-5. https://doi.org/10.1034/j. 1600-0536.2002.460101.x

Köhler CA, Freitas TH, Stubbs B, Maes M, Solmi M, Veronese N, de Andrade NQ et al (2018) Peripheral alterations in cytokine and chemokine levels after antidepressant drug treatment for major depressive disorder: systematic review and meta-analysis. Mol Neurobiol 55(5):4195-4206. https://doi.org/10.1007/ s12035-017-0632-1 
Komura K, Iwata Y, Ogawa F, Yoshizaki A, Yamaoka T, Akiyama Y, Hara T, Hasegawa M, Fujimoto M, Sato S (2009) Low zone tolerance requires ICAM-1 expression to limit contact hypersensitivity elicitation. J Investig Dermatol 129(11):2661-2667. https://doi. org/10.1038/jid.2009.145

Kubera M, Curzytek K, Majewska-Szczepanik M, Szczepanik M, Marcińska K, Ptak W, Leśkiewicz M et al (2012) Inhibitory effect of antidepressant drugs on contact hypersensitivity reaction. Pharmacol Rep 64(3):714-722. https://doi.org/10.1016/ S1734-1140(12)70866-6

Kubera M, Grygier B, Wrona D, Rogóż Z, Roman A, Basta-Kaim A, Budziszewska B et al (2011a) Stimulatory effect of antidepressant drug pretreatment on progression of $\mathrm{B} 16 \mathrm{~F} 10$ melanoma in high-active male and female C57BL/6J mice. J Neuroimmunol 240-241:34-44. https://doi.org/10.1016/j.jneuroim.2011.09.006

Kubera M, Kenis G, Bosmans E, Kajta M, Basta-Kaim A, Scharpe S, Budziszewska B, Maes M (2004) Stimulatory effect of antidepressants on the production of IL-6. Int Immunopharmacol 4(2):185192. https://doi.org/10.1016/j.intimp.2003.11.006

Kubera M, Maes M, Budziszewska B, Basta-Kaim A, Leśkiewicz M, Grygier B, Rogóż Z, Lasoń W (2009) Inhibitory effects of amantadine on the production of pro-inflammatory cytokines by stimulated in vitro human blood. Pharmacol Rep 61(6):1105-1112. https://doi.org/10.1016/S1734-1140(09)70173-2

Kubera M, Maes M, Holan V, Basta-Kaim A, Roman A, Shani J (2001) Prolonged desipramine treatment increases the production of interleukin-10, an anti-inflammatory cytokine, in C57BL/6 mice subjected to the chronic mild stress model of depression. J Affect Disord 63(1-3):171-178. https://doi.org/10.1016/S0165-0327(00) 00182-8

Kubera M, Obuchowicz E, Goehler L, Brzeszcz J, Maes M (2011b) In animal models, psychosocial stress-induced (neuro)inflammation, apoptosis and reduced neurogenesis are associated to the onset of depression. Prog Neuropsychopharmacol Biol Psychiatry 35(3):744-759. https://doi.org/10.1016/j.pnpbp.2010.08.026

Kubera M, Simbirtsev A, Mathison R, Maes M (2000) Effects of repeated fluoxetine and citalopram administration on cytokine release in C57BL/6 mice. Psychiatry Res 96(3):255-266. https:// doi.org/10.1016/S0165-1781(00)00184-0

Kubera M, Symbirtsev A, Basta-Kaim A, Borycz J, Roman A, Papp M, Claesson M (1996) Effect of chronic treatment with imipramine on interleukin 1 and interleukin 2 production by splenocytes obtained from rats subjected to a chronic mild stress model of depression. Pol J Pharmacol 48(5):503-506

Li XQ, Wang HM, Yang CG, Zhang XH, Han DD, Wang HL (2011) Fluoxetine inhibited extracellular matrix of pulmonary artery and inflammation of lungs in monocrotaline-treated rats. Acta Pharmacol Sin 32(2):217-222. https://doi.org/10.1038/aps.2010.187

Lin N-C, Chou J-y, Chen H, Chen V-H (2009) Sertraline-induced photoallergic reaction. J Clin Psychopharmacol 29(1):95-96. https:// doi.org/10.1097/JCP.0b013e31819304a5

Liu JJ, Wei YB, Strawbridge R, Bao Y, Chang S, Shi Le, Que J et al (2020) Peripheral cytokine levels and response to antidepressant treatment in depression: a systematic review and meta-analysis. Mol Psychiatry 25(2):339-350. https://doi.org/10.1038/ s41380-019-0474-5

Maes M, Bosmans E, Suy E, Vandervorst C, DeJonckheere C, Raus J (1991) Depression-related disturbances in mitogen-induced lymphocyte responses and interleukin- $1 \beta$ and soluble interleukin-2 receptor production. Acta Psychiatr Scand 84(4):379-386. https:// doi.org/10.1111/j.1600-0447.1991.tb03163.x

Maes M, Bosmans E, De Jongh R, Kenis G, Vandoolaeghe E, Neels H (1997) Increased serum IL-6 and IL-1 receptor antagonist concentrations in major depression and treatment resistant depression. Cytokine 9(11):853-858. https://doi.org/10.1006/cyto.1997.0238
Maes M, Song C, Lin AH, Bonaccorso S, Kenis G, De Jongh R, Bosmans E, Scharpé S (1999) Negative immunoregulatory effects of antidepressants inhibition of interferon- $\gamma$ and stimulation of interleukin-10 secretion. Neuropsychopharmacology 20(4):370-379. https://doi. org/10.1016/S0893-133X(98)00088-8

Maes M, Yirmyia R, Noraberg J, Brene S, Hibbeln J, Perini G, Kubera M, Bob P, Lerer B, Maj M (2009) The inflammatory \& neurodegenerative (I\&ND) hypothesis of depression: leads for future research and new drug developments in depression. Metab Brain Dis 24(1):27-53. https://doi.org/10.1007/s11011-008-9118-1

Majewska M, Szczepanik M (2009) Contact sensitivity reaction, its mechanism and regulation. Postepy Hig Med Dosw(Online) 63:47-57

Marron SE, Tomas-Aragones L, Navarro-Lopez J, Gieler U, Kupfer J, Dalgard FJ, Lien L et al (2018) The psychosocial burden of hand eczema: data from a European dermatological multicentre study. Contact Dermatitis 78(6):406-412. https://doi.org/10.1111/cod. 12973

Martín-Hernández D, Caso JR, Javier Meana J, Callado LF, Madrigal JLM, García-Bueno B, Leza JC (2018) Intracellular inflammatory and antioxidant pathways in postmortem frontal cortex of subjects with major depression: effect of antidepressants. J Neuroinflammation 15(1):1-12. https://doi.org/10.1186/s12974-018-1294-2

Martin SF, Dudda JC, Bachtanian E, Lembo A, Liller S, Dürr C, Heimesaat MM et al (2008) Toll-like receptor and IL-12 signaling control susceptibility to contact hypersensitivity. J Exp Med 205(9):2151-2162. https://doi.org/10.1084/jem.20070509

Martin SF, Dudda JC, Delattre V, Bachtanian E, Leicht C, Burger B, Simon JC (2004) 'Fas-mediated inhibition of CD4+ T cell priming results in dominance of type $1 \mathrm{CD} 8+\mathrm{T}$ cells in the immune response to the contact sensitizer trinitrophenyl'. J Immunol (Baltimore, Md. :1950) 173 (5): 3178-85. https://doi.org/10.4049/ jimmunol.173.5.3178 [pii].

Mattii M, Ayala F, Balato N, Filotico R, Lembo S, Schiattarella M, Patruno C, Marone G, Balato A (2013) The balance between pro- and anti-inflammatory cytokines is crucial in human allergic contact dermatitis pathogenesis: the role of IL-1 family members. Exp Dermatol 22(12):813-819. https://doi.org/10.1111/exd.12272

Mizumoto N, Iwabichi K, Nakamura H, Ato M, Shibaki A, Kawashima T, Kobayashi H, Iwabuchi C, Ohkawara A, Onoé K (2001) Enhanced contact hypersensitivity in human monocyte chemoattractant protein-1 transgenic mouse. Immunobiology 204(4):477493. https://doi.org/10.1078/0171-2985-00057

Nazimek K, Kozlowski M, Bryniarski P, Strobel S, Bryk A, Myszka M, Tyszka A, Kuszmiersz P, Nowakowski J, Filipczak-Bryniarska I (2016) Repeatedly administered antidepressant drugs modulate humoral and cellular immune response in mice through action on macrophages. Exp Biol Med 241(14):1540-1550. https://doi.org/ $10.1177 / 1535370216643769$

Niemeier V, Nippesen M, Kupfer J, Schill WB, Gieler U (2002) Psychological factors associated with hand dermatoses: which subgroup needs additional psychological care? Br J Dermatol 146(6):1031-1037. https://doi.org/10.1046/j.1365-2133.2002. 04716.x

O'Sullivan JB, Ryan KM, Harkin A, Connor TJ (2010) Noradrenaline reuptake inhibitors inhibit expression of chemokines IP-10 and RANTES and cell adhesion molecules VCAM-1 and ICAM-1 in the CNS following a systemic inflammatory challenge. J Neuroimmunol 220(1-2):34-42. https://doi.org/10.1016/j.jneuroim. 2009.12.007

Obuchowicz E, Bielecka AM, Paul-Samojedny M, Pudełko A, Kowalski J (2014) Imipramine and fluoxetine inhibit LPS-induced activation and affect morphology of microglial cells in the rat glial culture. Pharmacol Rep 66(1):34-43. https://doi.org/10.1016/j.pharep. 2013.08.002 
Ogawa A, Yoshizaki A, Yanaba K, Ogawa F, Hara T, Muroi E, Takenaka $\mathrm{M}$ et al (2010) The differential role of L-selectin and ICAM-1 in Th1-type and Th2-type contact hypersensitivity. J Investig Dermatol 130(6):1558-1570. https://doi.org/10. 1038/jid.2010.25

Qin L, Xuefei Wu, Block ML, Liu Y, Breese GR, Hong J-S, Knapp DJ, Crews FT (2007) Systemic LPS causes chronic neuroinflammation and progressive neurodegeneration. Glia 55(5):453-462. https:// doi.org/10.1002/glia.20467

Rami M, Guillamat-Prats R, Rinne P, Salvermoser M, Ring L, Bianchini M, Blanchet X et al (2018) Chronic intake of the selective serotonin reuptake inhibitor fluoxetine enhances atherosclerosis. Arterioscler Thromb Vasc Biol 38(5):1007-1019. https://doi.org/10.1161/ ATVBAHA.117.310536

Ritprajak P, Hayakawa M, Sano Y, Otsu K, Park JM (2012) Cell typespecific targeting dissociates the therapeutic from the adverse effects of protein kinase inhibition in allergic skin disease. Proc Natl Acad Sci 109(23):9089-9094. https://doi.org/10.1073/pnas. 1202984109

Roumestan C, Michel A, Bichon F, Portet K, Detoc M, Henriquet C, Jaffuel D, Mathieu M (2007) Anti-inflammatory properties of desipramine and fluoxetine Respir Res 8 https://doi.org/10.1186/ 1465-9921-8-35

Ruggiero P, Flati S, Di Cioccio V, Maurizi G, Macchia G, Facchin A, Anacardio R, Maras A, Lucarelli M, Boraschi D (2003) Glycosylation enhances functional stability of the chemotactic cytokine CCL2. Eur Cytokine Netw 14(2):91-96

Sakai H, Ishida T, Sato K, Mandokoro K, Yabe S, Sato F, Chiba Y, Kon R, Ikarashi N, Kamei J (2019) Interference of skin scratching attenuates accumulation of neutrophils in murine allergic contact dermatitis model. Inflammation 42(6):2226-2235. https://doi.org/ 10.1007/s10753-019-01086-y

Sanz-Gallén P, Nogué S, Herrera-Mozo I, Delclos GL, Valero A (2011) Occupational contact allergy to omeprazole and fluoxetine. Contact Dermatitis 65(2):118-119. https://doi.org/10.1111/j.16000536.2011.01931.x

Silvestre MC, Silva VM, dos Reis, and Maria Notomi Sato. (2018) Innate immunity and effector and regulatory mechanisms involved in allergic contact dermatitis. An Bras Dermatol 93(2):242-250. https://doi.org/10.1590/abd1806-4841.20186340

Ślusarczyk J, Trojan E, Głombik K, Piotrowska A, Budziszewska B, Kubera M, Popiołek-Barczyk K, Lasoń W, Mika J, Basta-Kaim A (2018) Targeting the NLRP3 inflammasome-related pathways via tianeptine treatment-suppressed microglia polarization to the M1 phenotype in lipopolysaccharide-stimulated cultures. Int J Mol Sci 19(7):1-23. https://doi.org/10.3390/ijms 19071965

Summer B, Ständer S, Thomas P (2018) Cytokine patterns in vitro, in particular IL-5/IL-8 ratio, to detect patients with nickel contact allergy. J Eur Acad Dermatol Venereol 32(9):1542-1548. https:// doi.org/10.1111/jdv.14931

Teijeira A, Hunter MC, Russo E, Proulx ST, Frei T, Debes GF, Coles M et al (2017) T cell migration from inflamed skin to draining lymph nodes requires intralymphatic crawling supported by ICAM-1/ LFA-1 interactions. Cell Rep 18(4):857-865. https://doi.org/10. 1016/j.celrep.2016.12.078

Thomas AJ, Ferrier IN, Kalaria RN, Woodward SA, Ballard C, Oakley A, Perry RH, O’Brien JT (2000) Elevation in late-life depression of intercellular adhesion molecule-1 expression in the dorsolateral prefrontal cortex. Am J Psychiatry 157(10):1682-1684. https:// doi.org/10.1176/appi.ajp.157.10.1682

Thyssen JP, Linneberg A, Menné T, Johansen JD (2007) The epidemiology of contact allergy in the general population-prevalence and main findings. Contact Dermatitis 57(5):287-299. https://doi. org/10.1111/j.1600-0536.2007.01220.x

Trojan E, Ślusarczyk J, Chamera K, Kotarska K, Głombik K, Kubera M, Basta-Kaim A (2017) The modulatory properties of chronic antidepressant drugs treatment on the brain chemokine-chemokine receptor network: a molecular study in an animal model of depression. Front Pharmacol 8 (NOV): 1-16. https://doi.org/10.3389/ fphar.2017.00779

Troubat R, Barone P, Leman S, Desmidt T, Cressant A, Atanasova B, Camus V (2021) Neuroinflammation and depression : a review, no. August 2019: 1-21. https://doi.org/10.1111/ejn.14720

Wędzony K, Chocyk A, Maćkowiak M (2013) Potential roles of NCAM/PSA-NCAM proteins in depression and the mechanism of action of antidepressant drugs. Pharmacol Rep 65(6):1471-1478. https://doi.org/10.1016/S1734-1140(13)71507-X

Xia BT, Beckmann N, Winer LK, Pugh AM, Pritts TA, Nomellini V, Caldwell CC (2019) Amitriptyline reduces inflammation and mortality in a murine model of sepsis. Cell Physiol Biochem 52 (3): 565-79. https://doi.org/10.33594/000000040

Xia Z, DePierre JW, Nässberger L (1996) Tricyclic antidepressants inhibit IL-6, IL- $1 \beta$ and TNF- $\alpha$ release in human blood monocytes and IL- 2 and interferon- $\gamma$ in T cells. Immunopharmacology 34(1):27-37. https://doi.org/10.1016/0162-3109(96)00111-7

Yang JM, Rui BB, Chen C, Chen H, Xu TJ, Xu WP, Wei W (2014) Acetylsalicylic acid enhances the anti-inflammatory effect of fluoxetine through inhibition of NF-KB, P38-MAPK and ERK1/2 activation in lipopolysaccharide-induced BV-2 microglia cells. Neuroscience 275:296-304. https://doi.org/10.1016/j.neuroscien ce.2014.06.016

Publisher's Note Springer Nature remains neutral with regard to jurisdictional claims in published maps and institutional affiliations. 